\title{
Physical Processes, Salinity Characteristics, and Potential Salinity Changes due to Freshwater Withdrawals in the Tidal Myakka River, Florida
}

By K.M. Hammett

U.S. GEOLOGICAL SURVEY

Water-Resources Investigations Report 90-4054

Prepared in cooperation with the SARASOTA COUNTY, FLORIDA 


\section{U.S. DEPARTMENT OF THE INTERIOR \\ MANUEL LUJAN, JR., Secretary}

\section{U.S. GEOLOGICAL SURVEY \\ Dallas L. Peck, Director}

For additional information write to:

District Chief

U.S. Geological Survey

Suite 3015

227 North Bronough Street

Tallahassee, Florida 32301
Copies of this report may be purchased from:

U.S. Geological Survey

Books and Open-File Reports Section

Federal Center, Building 810

Box 25425

Denver, Colorado 80225 


\title{
CONTENTS
}

\author{
Abstract 1 \\ Introduction 1 \\ Area description 3 \\ Physical processes in the tidal reach $\mathbf{3}$ \\ Freshwater inflow 4 \\ Data network 5 \\ Frequency analyses 6 \\ Duration analyses 6 \\ Tides 8 \\ Data network 9 \\ Tidal range 9 \\ Duration analyses 11 \\ Salinity characteristics 11 \\ Data network 12 \\ Salinity range 12 \\ Duration analyses 14 \\ Regression analysis 14 \\ Potential salinity changes due to freshwater withdrawals $\mathbf{1 8}$ \\ Summary 19 \\ Selected references 20
}

FIGURES

1-2. Maps showing the:

1. Myakka River basin and Charlotte Harbor 2

2. Tidal reach of the Myakka River 4

3-5. Graphs showing typical tidal patterns associated with:

3. Low freshwater inflow 9

4. Medium freshwater inflow $\mathbf{1 0}$

5. High freshwater inflow $\mathbf{1 0}$

6. Diagrams showing highly stratified, partially mixed, and well mixed conditions in the tidal reach $\mathbf{1 2}$

7-9. Graphs showing typical salinity patterns associated with:

7. Low freshwater inflow 13

8. Medium freshwater inflow $\mathbf{1 3}$

9. High freshwater inflow 14

10-12. Graphs showing:

10. Vertical profiles of salinity at selected locations during low, medium, and high freshwater inflow $\mathbf{1 6}$

11. Percentiles of daily mean salinities along the tidal reach $\mathbf{1 6}$

12. Freshwater inflow and high tide, and location of 0.5 -part-per-thousand line of equal salinity computed from regression equation $\mathbf{1 8}$ 


\section{TABLES}

1. Continuous-record streamflow, stage, and conductivity stations 5

2. Low-flow frequency distribution for the Myakka River near Sarasota (station 02298830) 7

3. Estimated low-flow frequency distribution for the Myakka River at the control near Laurel (station 02298880) 7

4. Duration analyses of streamflow at the Myakka River near Sarasota (station 02298830) 7

5. Estimated duration analyses of streamflow at the Myakka River at the control near Laurel (station 02298880) 8

6. Characteristics of runoff in the Myakka River basin 8

7. Duration analyses of daily maximum stage at the Myakka River at El Jobean (station 02299496) 11

8. Vertical profiles of salinity near the Myakka River at El Jobean (station 02299496) 15

9. Percentiles of daily mean salinities at stations along the tidal reach $\mathbf{1 6}$

10. Duration analyses of daily maximum salinity at the Myakka River at El Jobean (station 02299496) 16

11. Duration analyses of daily maximum salinity at the Myakka River at North Port (station 02299230) 17

12. Duration analyses of daily maximum salinity at the Myakka River at Snook Haven Fish Camp near Venice (station 02298955) 17

13. Duration analyses of daily maximum salinity at the Myakka River near Venice (Border Road) (station 02298930) 17

14. Duration analyses of farthest upstream movement of the 0.5-part-per-thousand line of equal salinity, 1983-87 19

\section{METRIC CONVERSION FACTORS}

\begin{tabular}{lcll}
\hline \multicolumn{1}{c}{ Multiply } & By & To obtain \\
\hline inch (in.) & 25.4 & millimeter \\
foot $(\mathrm{ft})$ & 0.3048 & meter \\
mile $(\mathrm{mi})$ & 1.609 & kilometer \\
foot per mile $(\mathrm{ft} / \mathrm{mi})$ & 0.1894 & meter per kilometer \\
square mile $\left(\mathrm{mi}^{2}\right)$ & 2.590 & square kilometer \\
acre & 0.4047 & hectare \\
cubic foot per second & 0.02832 & cubic meter per second \\
$\left(\mathrm{ft}^{3} / \mathrm{s}\right)$ & & \\
million gallons (Mgal) & 3,785 & cubic meter \\
million gallons per day & 0.04381 & cubic meter per second \\
(Mgal/d) & & \\
\hline
\end{tabular}

Sea level: In this report, "sea level" refers to the National Geodetic Vertical Datum of 1929 (NGVD of 1929)--a geodetic datum derived from a general adjustment of the first-order level nets of both the United States and Canada, formerly called Sea Level Datum of 1929.

\section{ADDITIONAL ABBREVIATIONS}

parts per thousand (ppt)

Regional Observation and Monitor Well Program (ROMP) 


\section{Physical Processes, Salinity Characteristics, and Potential Salinity Changes due to Freshwater Withdrawals in the Tidal Myakka River, Florida}

\author{
By K.M. Hammett
}

\begin{abstract}
The Myakka River, a coastal stream in west-central Florida, is one of three major tributaries to Charlotte Harbor. The river is being evaluated as a potential source of water for municipal supply. Reducing freshwater inflow through withdrawals could alter salinity patterns in the tidal reach, which, in turn, would affect the ecosystem. An understanding of the relation between freshwater inflow, tidal movement, and salinity is essential to evaluating the potential effect of freshwater
\end{abstract} diversion.

Mean freshwater inflow at the upstream end of the tidal reach is about 340 cubic feet per second. Median freshwater inflow is about 100 cubic feet per second, indicating a skewed distribution. About 25 percent of the time, inflow at the upstream end of the tidal reach is less than 10 cubic feet per second. It is estimated that there is a 20-percent chance that there will be no freshwater inflow in this reach for 90 consecutive days in any year.

The daily oscillation in stage at the downstream end of the tidal reach averaged 2.2 feet during the period of record, 1983-87. During periods of low flow, backwater effects from tide were observed as far as 28.7 miles upstream from the mouth. At river mile 26.1, the daily fluctuation in stage averaged about 0.45 foot during most of the year.

The tidal reach of the Myakka River is normally well mixed, and stratification occurs only during periods of high flow. At El Jobean (near the mouth), salinity averaged 16.7 parts per thousand for the period of record. Near North Port (about 11 miles upstream), salinity averaged 5.1 parts per thousand. At Snook Haven Fish Camp (about 18 miles upstream), there was no daily variation in sal inity about 50 percent of the time. In the summer of 1985, however, salinity exceeded 15 parts per thousand at Snook Haven and exceeded 10 parts per thousand at Border Road (about 21 miles upstream) following an extended period of low streamflow.

For purposes of this study, the transition from freshwater to saltwater is defined as the 0.5-part-per-thousand line of equal salinity. The farthest upstream incursion of saltwater on a daily basis was estimated by regression analysis as a function of freshwater inflow and height of tide. Farthest incursion averaged about 14 miles upstream from the mouth. On some days, saltwater may have reached as far as the control structure 28.7 miles upstream from the mouth. The 0.5 -part-per-thousand line of equal salinity reached at least 7.0 miles upstream from the mouth every day during the period of record, 1983-87.

Diverting 5 percent of the freshwater inflow and maintaining regulatory minimum monthly streamflows at the upstream end of the tidal reach would result in saltwater moving an average of 0.1 mile farther upstream. A 10-percent diversion would result in the freshwater-saltwater interface moving farther upstream an average of 0.2 mile and a maximum of 0.7 mile. A 25-percent diversion at the upstream end of the tidal reach would allow saltwater to move farther upstream an average of 0.6 mile and a maximum of 1.9 miles.

\section{INTRODUCTION}

The population of Sarasota County in southwestern Florida (fig. 1) is expected to increase from 238,000 in 1985 to 387,000 in 2010 (Bureau of Economic and Business Research, 1985). To accommodate this growth and the accompanying demand for water, it is estimated that the county will need to supply an additional $36 \mathrm{Mgal}$ of water per day by 2010 (Dames and Moore, Inc., 1985). Sarasota County is currently investigating the water-supply development potential of the Ringling-MacArthur Reserve, a 33,000-acre tract in the central part of the county. The Myakka River, which forms the western border of the Reserve (fig. 1), is being considered as a potential source of water for municipal supply.

The Myakka River is the smallest of the three major tributaries to Charlotte Harbor (fig. 1). Average freshwater inflow from the Myakka River basin to Charlotte Harbor is estimated to be about 10 percent of the total freshwater inflow to the harbor (Hammett, 1990). Withdrawing freshwater from the Myakka River, or its tributaries, will reduce inflow to the harbor and alter salinity patterns in the tidal reach of the river.

Salinity is a critical factor affecting the existence of many estuarine organisms. Changes in salinity patterns can cause changes in biological systems that could have long-term detrimental effects on the ecological balance of the tidal reach of the Myakka River. To evaluate the potential 


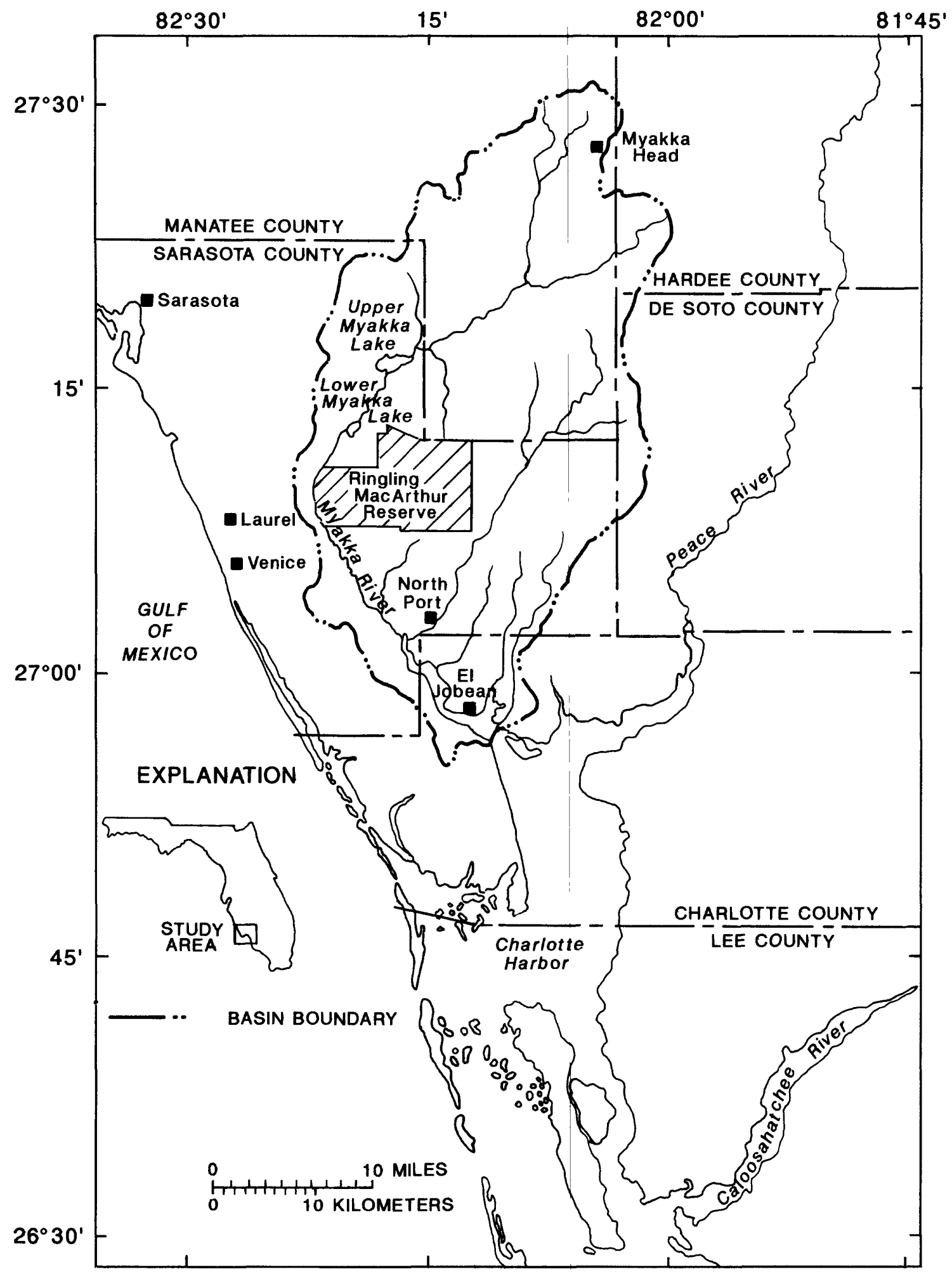

Figure 1. Location of the Myakka River Basin and Charlotte Harbor. 
environmental consequences of using the Myakka River as a source of water supply, it is essential to understand the relation between freshwater inflow, tidal movement, and salinity patterns. An analysis of the interaction of these factors is needed by water-resource planners and managers before development of additional water supply from this source can proceed. To obtain the needed information, the U.S. Geological Survey entered into a cooperrative study with Sarasota County. Prior to that, tide-stage and salinity data for the study area were collected by the U.S. Geological Survey, in cooperation with the Florida Department of Environmental Regulation, as part of an environmental assessment of Charlotte Harbor.

This report provides results of a study of streamflow, tide, and salinity patterns in the tidal reach of the Myakka River, including a mathematical expression describing saltwater movement as a function of measured streamflow and tide. The results are based on data collected between 1983 and 1987. A salinity of 0.5 ppt was selected to define the transition from freshwater to saltwater. An equation that describes the farthest upstream movement of the 0.5-ppt line as a function of daily mean freshwater inflow and height of high tide was developed using multiple linear-regression analysis. Duration analyses of data from continuous-record streamflow, tidal stage, and conductivity stations were used to describe the existing freshwater inflow, tide, and salinity characteristics of the tidal reach of the Myakka River. Daily tide and streamflow records were used in the regression equation to produce duration analyses of the farthest upstream movement of the 0.5 -ppt line of equal salinity during the period 1983-87. The regression equation also was used to estimate the change in location of the 0.5-ppt line of equal salinity that would result from diverting 5,10 , or 25 percent of the streamflow at the upper end of the tidal reach while at the same time maintaining the minimum allowable flows in the Myakka River.

\section{AREA DESCRIPTION}

The Myakka River is in the coastal lowlands of west-central Florida and drains an area of $602 \mathrm{mi}^{2}$ (fig. 1). Its headwaters are in eastern Manatee County near Myakka Head. The river flows in a southerly direction through Upper and Lower Myakka Lakes and Manatee, Sarasota, and Charlotte Counties before emptying into the northwestern corner of Charlotte Harbor. Although the river tranverses a linear distance of only about $50 \mathrm{mi}$, the distance along the meandering channel from headwaters to river mouth is more than 70 river miles.

The river channel is incised in a flat, broad, heavily vegetated flood plain. Land-surface elevations range from a maximum of about $115 \mathrm{ft}$ above sea level near the headwaters to sea level at the mouth. In the upper reaches, the basin has a slope of about $5 \mathrm{ft} / \mathrm{mi}$. Near the mouth, the slope is less than $1 \mathrm{ft} / \mathrm{mi}$.

Surface depressions, marshes, and swamps within the Myakka River basin provide large storage areas for overflow. The flat topography, combined with large storage areas, tends to produce very gradual rises and recessions in streamflow. In some areas of the basin, dikes have been constructed to protect agricultural land from perennial flooding.

The tidal reach of the Myakka River extends more than $25 \mathrm{mi}$ upstream from the mouth at Cattle Dock Point and generally is quite shallow. Near center channel, the depth of the river typically ranges from 4 to $8 \mathrm{ft}$. There are some points near the mouth with depths of more than $15 \mathrm{ft}$, but the river is less than $1 \mathrm{ft}$ deep near the upstream end during low flows. Upstream from Snook Haven Fish Camp (fig. 2, station 5), the channel is fairly well incised and is less than 50 $\mathrm{ft}$ wide in some places. Downstream from U.S. Highway 41 (fig. 2, station 6), there are broad expanses of saltmarsh, and the river is more than a mile wide near the mouth.

Within the tidal reach, three subreaches can be defined. The boundaries of these subreaches vary depending on the interaction of tide and freshwater inflow. At the downstream end of the tidal reach is an estuarine subreach that has both tidal fluctuations and flow reversals as well as salinity concentrations that range from slightly brackish to that of seawater. During periods of low freshwater inflow, the estuarine subreach may extend from the mouth to Border Road (fig. 2, station 4). During periods of high freshwater inflow, the estuarine subreach typically extends from the mouth to U.S. Highway 41 (fig. 2, station 6). Upstream from the estuarine subreach is a freshwater subreach that has tidal fluctuation in stage and flow reversals. During high freshwater inflows, flow reversals do not occur at Snook Haven Fish Camp (fig. 2, station 5). During low freshwater inflows, flow reversals have been observed as far upstream as the gaging station near Laurel (fig. 2, station 3). At the upstream end of the tidal reach is another freshwater subreach where the direction of flow does not change, but where tidal fluctuations produce backwater effects that result in variations in water level and flow velocity. The continuousrecord stage station near Laurel (fig. 2, station 3) shows a daily stage oscillation during most of the year. Stage data from the continuous-record station at the control near Laurel (fig. 2, station 2) shows some effects from tidal backwater during the low-flow season.

\section{PHYSICAL PROCESSES IN THE TIDAL REACH}

In the tidal reach, the interaction of freshwater inflow, ocean tides, wind, channel geometry, and density differences all affect the movement of water. Freshwater inflow and 


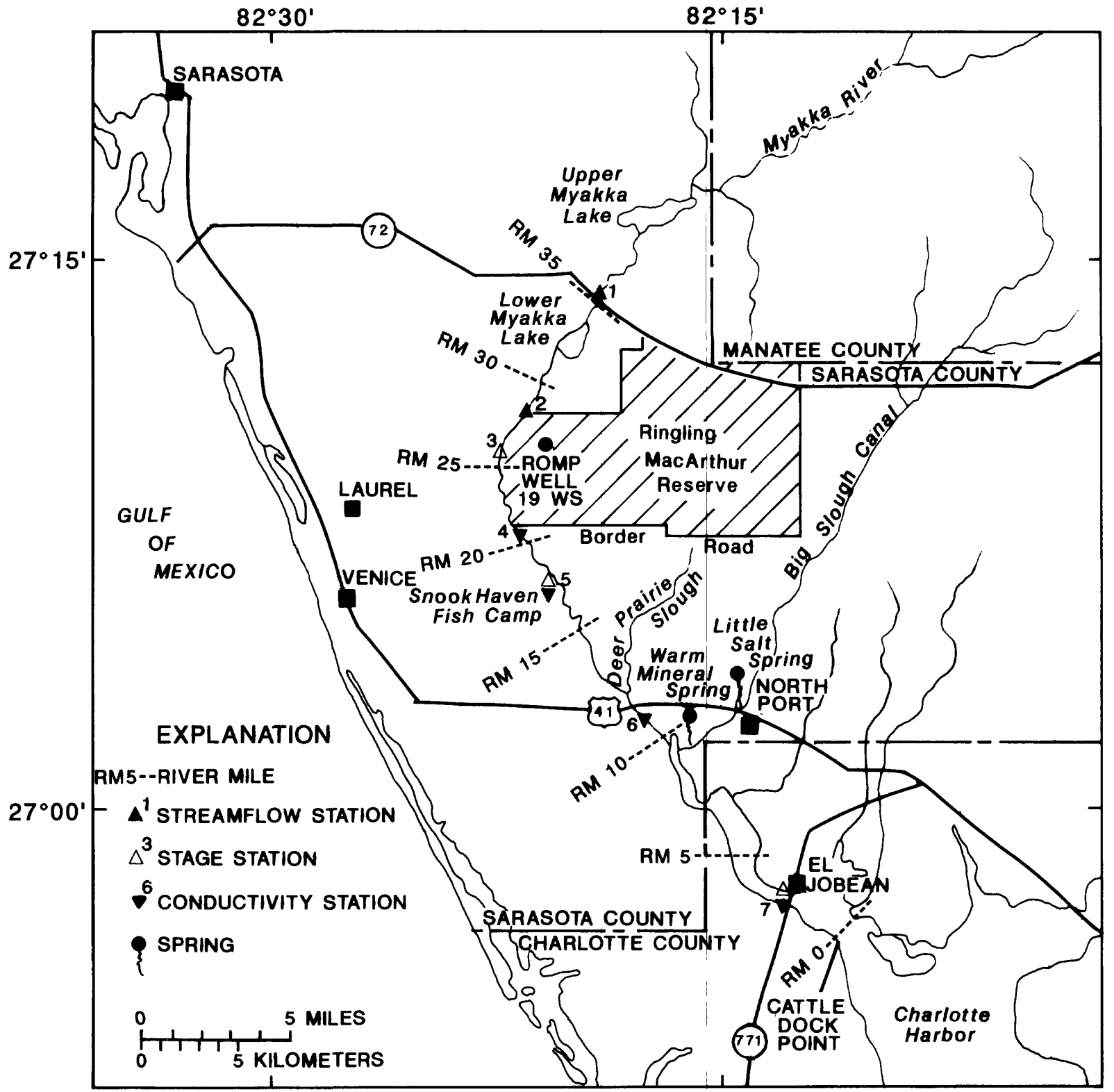

Figure 2. Tidal reach of the Myakka River.

astronomical tides, which are discussed individually in the following two sections, have the most significant effect. Most of the time, interacting forces in the tidal reach of the Myakka River inhibit stratification and promote the mixing of freshwater with saltwater. Because of the flat slope of the tidal reach, freshwater inflows tend to have low velocities. The shallowness of the channel increases the frictional effects from the channel bottom and also makes the tidal reach more susceptible to wind-induced mixing. The difference in density between saltwater and freshwater causes partly or fully stratified conditions only when high freshwater inflows meet strong opposing tidal currents, in which case, the lessdense freshwater overlies the heavier, tidally driven saltwater.

\section{Freshwater Inflow}

There are three potential sources of freshwater inflow, all of which are ultimately derived from rainfall: (1) groundwater seepage and inflow; (2) rain falling directly onto the surface of the tidal reach; and (3) basin runoff or incoming streamflow.

There is no direct way of measuring ground-water seepage in the tidal reach. ROMP well 19 WS near Sarasota (fig. 2) is about $1.25 \mathrm{mi}$ east of the river channel in the Ringling-MacArthur Reserve and is the nearest surficial aquifer monitoring site. Comparison of the hydrograph for that weIl with stage record for the Myakka River near Laurel shows that water levels in the surficial aquifer near ROMP 19 are 10 to $15 \mathrm{ft}$ higher than the Myakka River during periods of low flow. This hydraulic gradient indicates a potential for flow from the surficial aquifer system to the river. There has 
been no detectable flow in the river, however, during some of the times when this 10 - to 15 - $\mathrm{ft}$ gradient was observed. This would indicate that, despite the gradient, the contribution from the surficial aquifer system is limited.

Warm Mineral Springs and Little Salt Spring (fig. 2) are sources of discharge from the Floridan aquifer (Joyner and Sutcliffe, 1976; Rosenau and others, 1977) that empty into tributaries to the tidal reach of the Myakka River. There may be other smaller springs of this type in the area that are filled with debris and, therefore, not noticeable at ground surface. It is probable that any spring flow or artesian ground-water seepage is mineralized and, therefore, negligible as a source of freshwater inflow.

Normal annual rainfall (1951-80) at Myakka River State Park is 56.81 in. (National Oceanic and Atmospheric Administration, 1987). The surface area of the tidal reach from Cattle Dock Point to the bridge at U.S. Highway 41 is about $9 \mathrm{mi}^{2}$. From U.S. Highway 41 to the Myakka River near Laurel (fig. 2, station 3), the surface area is about $0.5 \mathrm{mi}^{2}$. Therefore, rain falling on the surface of the tidal reach contributes the average annual equivalent of $38 \mathrm{ft}^{3} / \mathrm{s}$ of freshwater downstream from U.S. Highway 41 and about 2 $\mathrm{ft}^{3} / \mathrm{s}$ of freshwater upstream from U.S. Highway 41.

Basin runoff, or incoming streamflow, is the primary source of freshwater in the tidal reach of the Myakka River. Estimates of runoff and streamflow are based on data from continuous-record gaging stations. A description of the data-collection network and the characteristics of streamflow follows.

\section{Data Network}

Continuous-record streamflow stations used in this study are listed in table 1 and shown in figure 2 . The station near Laurel (fig. 2, station 3) originally was intended as a continuous-record streamflow station, but when it was determined that the flow at the site was tidally affected during most of the year, a station was installed farther upstream at the control near Laurel (fig. 2, station 2). In addition to the stations listed, there are others in the Myakka River basin that have been either discontinued or are outside the area of interest. Streamflow also has been measured occasionally at miscellaneous locations throughout the basin (Flippo and Joyner, 1968; Hammett, 1985).

Estimates of streamflow entering the tidal reach of the Myakka River are based primarily on more than 50 years of record at the long-term gaging station near Sarasota (fig. 2, station 1). Direct downstream translation of discharge is unreliable due to the storage capacity of Lower Myakka Lake. The relation between stage near Sarasota and stage at the control near Laurel (fig. 2, station 2) is quite stable. A regression, based on stage, was used to transfer information from the long-term station near Sarasota downstream to the upper end of the tidal reach (fig. 2, station 2). The translated stage was then used to estimate discharge using the stage-discharge relation established at the control near Laurel.

The regression equation that defines the relation between stage at the Myakka River near Sarasota and stage at the control near Laurel (fig. 2, station 2) is presented below as equation 1 . The equation is computed from 497

Table 1. Continuous-record streamflow, stage, and conductivity stations $\left[\mathrm{mi}^{2}\right.$, square miles]

\begin{tabular}{|c|c|c|c|c|}
\hline $\begin{array}{c}\text { Site } \\
\text { number }\end{array}$ & $\begin{array}{l}\text { Station } \\
\text { name and number }\end{array}$ & $\begin{array}{c}\text { Drainage } \\
\text { arga } \\
\left(\mathrm{mi}^{2}\right)\end{array}$ & $\begin{array}{l}\text { Period } \\
\text { of } \\
\text { record } \\
\end{array}$ & $\begin{array}{c}\text { Type } \\
\text { of } \\
\text { data } \\
\end{array}$ \\
\hline 1 & $\begin{array}{l}\text { Myakka River near Sarasota } \\
(02298830)\end{array}$ & 229 & $8 / 36$-present & $\begin{array}{l}\text { Stage } \\
\text { Streamflow }\end{array}$ \\
\hline 2 & $\begin{array}{l}\text { Myakka River at the control } \\
\text { near Laurel }(02298880)\end{array}$ & 253 & 3/86-present & $\begin{array}{l}\text { Stage } \\
\text { Streamflow }\end{array}$ \\
\hline 3 & $\begin{array}{l}\text { Myakka River near Laurel } \\
(02298900)\end{array}$ & 258 & 2/85-present & Stage \\
\hline 4 & $\begin{array}{l}\text { Myakka River near Venice } \\
(02298930)\end{array}$ & 272 & $4 / 86-12 / 86$ & Conductivity \\
\hline 5 & $\begin{array}{l}\text { Myakka River at Snook } \\
\text { Haven Camp near Venice } \\
\text { (02298955) }\end{array}$ & 283 & $8 / 83-6 / 87$ & $\begin{array}{l}\text { Stage } \\
\text { Conductivity }\end{array}$ \\
\hline 6 & $\begin{array}{l}\text { Myakka River at North Port } \\
(02299230)\end{array}$ & 358 & $6 / 83-6 / 87$ & Conductivity \\
\hline 7 & $\begin{array}{l}\text { Myakka River at E1 Jobean } \\
(02299496)\end{array}$ & 580 & $10 / 83-6 / 87$ & $\begin{array}{l}\text { Stage } \\
\text { Conductivity }\end{array}$ \\
\hline
\end{tabular}


concurrent records of daily mean stage at the two stations; the correlation coefficient is 0.95 . The relation is significant at the 1-percent level and has a standard error of estimate averaging 12 percent.

\section{STAGE AT CONTROL $=0.00039 *(\text { STAGE AT SARASOTA })^{3.642}$}

where

STAGE AT CONTROL = water-surface elevation at the Myakka River at the control near Laurel, in feet above sea level (estimated gage datum is $1.5 \mathrm{ft}$ above sea level),

STAGE AT SARASOTA = water-surface elevation at the Myakka River near Sarasota, in feet above sea level (gage datum is $7.92 \mathrm{ft}$ above sea level).

The accuracy of the stage estimate at the control can be improved by including the stage at the downstream station near Laurel (fig. 2, station 3) in a multiple regression, as defined in equation 2. The equation is computed from 497 concurrent records of daily mean stage at the three stations; the correlation coefficient is 0.99 . The relation is significant at the 1-percent level and has a standard error of estimate averaging 4.4 percent.

STAGE AT CONTROL

$$
\begin{aligned}
& =0.42836 *(\text { STAGE AT SARASOTA })^{0.653} \\
& *(\text { STAGE AT LAUREL }) \\
& 0.648
\end{aligned}
$$

where

\section{STAGE AT CONTROL and STAGE AT SARASOTA are} defined as in equation 1 ,

STAGE AT LAUREL = water-surface elevation at the Myakka River near Laurel, in feet above sea level (estimated gage datum is $0.0 \mathrm{ft}$ above sea level).

\section{Frequency Analyses}

A low-flow frequency distribution for the long-term gaging station at the Myakka River near Sarasota (fig. 2, station 1) is presented in table 2. The distribution is based on daily mean flows for the period of record through 1987 . The 2-year recurrence interval, 14-day low flow is $0 \mathrm{ft}^{3} / \mathrm{s}$, which means that, in any year, there is a 50-percent chance that there will be no flow at the site for 14 consecutive days. The 10-year recurrence interval, 90-day low flow is also $0 \mathrm{ft}^{3} / \mathrm{s}$, which means that, in any year, there is a 10-percent chance that there will be no flow for 90 consecutive days.

An estimated low-flow frequency distribution for the gaging station at the Myakka River at the control near Laurel (fig. 2, station 2) is presented in table 3. The distribution was computed by first converting the discharges at the long-term station near Sarasota (table 2) to stages using the latest station rating. Equation 1 was then used to estimate stage at the Myakka River at the control near Laurel. The stagedischarge rating at the control was then used to produce estimates of discharge for selected recurrence intervals and consecutive-day periods. This procedure is subject to inaccuracy because of the error in the stage-discharge ratings and the error in equation 1 , and the resulting distribution should be used with discretion. The procedure does provide a way of estimating a distribution at the upstream end of the tidal reach until a longer period of record becomes available at the control.

The frequency distribution in table 3 does conform to the observed characteristics of flow at the control. During periods of low flow, discharge at the long-term station near Sarasota is frequently higher than the discharge downstream because water is held in storage in Lower Myakka Lake where evaporation and vegetative transpiration remove water. Based on the estimated frequency distribution, in any year, there is a 20 -percent chance that there will be no flow at the control for 90 consecutive days.

\section{Duration Analyses}

Duration analyses of daily mean streamflow, by month, are presented in table 4 for the long-term station near Sarasota (fig. 2, station 1). Also shown are monthly mean, high, and low values. The median (50th percentile) streamflow is substantially lower than the mean in all cases. This indicates that computed averages are strongly affected by infrequent high flows, and thus, the computed average is not representative of typical flow patterns at the station. Characteristically, the lowest streamflows occur in May. During the period of record, 50 percent of the daily mean flows in May were less than or equal to $2.7 \mathrm{ft}^{3} / \mathrm{s}$, and 75 percent of the daily mean flows were less than or equal to $24 \mathrm{ft}^{3} / \mathrm{s}$. For all months from December through July, the recorded minimum flow at the station was 0 $\mathrm{ft}^{3} / \mathrm{s}$. Based on the record for all days, the daily mean flow at the station was less than $8.9 \mathrm{ft} 3 / \mathrm{s} 25$ percent of the time.

Estimated duration analyses of daily mean streamflow for the Myakka River at the control near Laurel (fig. 2, station 2) are presented in table 5. The estimates were derived using the same method presented in the discussion of low-flow frequency. Streamflows in table 4 were converted to stage using the most recent stage- discharge rating. Equation 1 was then used to estimate stage at the control, and the stagedischarge rating at the control was used to convert the results from equation 1 to discharge. The estimates in table 5 conform to the observed characteristics at the station. During most of the year, the discharge at the control was greater than at the upstream long-term station. But during periods of low flow, discharge at the control was less than that upstream, most likely due to water storage and subsequent evaporation 
Table 2. Low-flow frequency distribution for the Myakka River near Sarasota (station 02298830)

[Period of record, 1937-87]

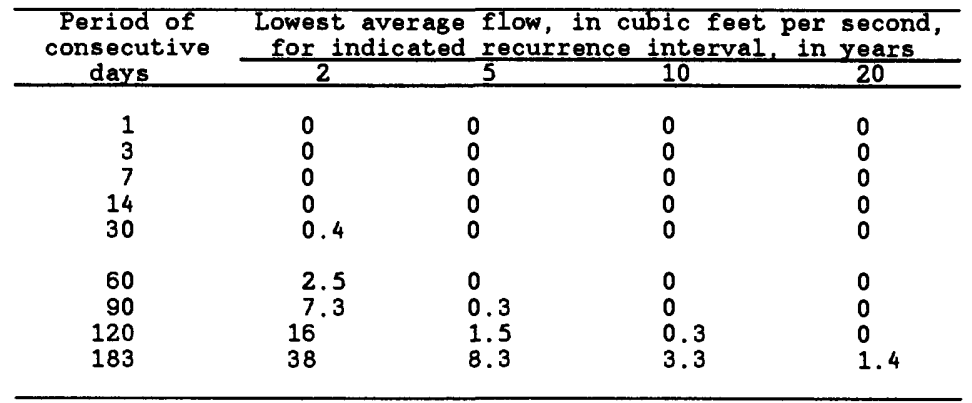

Table 3. Estimated low-flow frequency distribution for the Myakka River at the control near Laurel (station 02298880)

[Derived from equation 1]

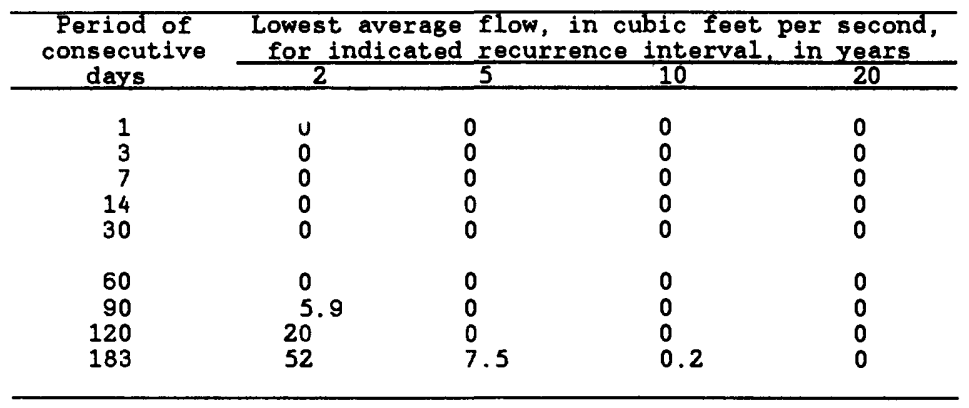

Table 4. Duration analyses of streamflow at the Myakka River near Sarasota (station 02298830)

[Period of record, 1937-87]

\begin{tabular}{|c|c|c|c|c|c|c|c|c|}
\hline \multirow[b]{2}{*}{ Month } & \multicolumn{3}{|c|}{ Daily mean } & \multirow{2}{*}{\multicolumn{2}{|c|}{$\begin{array}{l}\text { treamflow, in cubic } \\
\text { Percent of time }\end{array}$}} & \multicolumn{3}{|c|}{ feet per second } \\
\hline & Mean & $\mathrm{High}$ & Low & & & $\frac{\frac{1 e s s}{50}}{50}$ & $\frac{\operatorname{than} \text { or }}{75}$ & $\begin{array}{r}\text { equal to } \\
90\end{array}$ \\
\hline $\begin{array}{l}\text { January } \\
\text { February } \\
\text { March }\end{array}$ & $\begin{array}{l}104 \\
118 \\
154\end{array}$ & $\begin{array}{l}1,620 \\
1,270 \\
2,200\end{array}$ & $\begin{array}{r}0.00 \\
.00 \\
.00\end{array}$ & $\begin{array}{r}1.7 \\
.8 \\
.1\end{array}$ & $\begin{array}{l}7.6 \\
8.1 \\
6.2\end{array}$ & $\begin{array}{l}24 \\
38 \\
40\end{array}$ & $\begin{array}{l}128 \\
152 \\
167\end{array}$ & $\begin{array}{l}329 \\
341 \\
468\end{array}$ \\
\hline $\begin{array}{l}\text { April } \\
\text { May } \\
\text { June }\end{array}$ & $\begin{array}{r}89 \\
30 \\
170\end{array}$ & $\begin{array}{r}1,870 \\
738 \\
3,850\end{array}$ & $\begin{array}{l}.00 \\
.00 \\
.00\end{array}$ & $\begin{array}{l}.0 \\
.0 \\
.0\end{array}$ & $\begin{array}{l}.8 \\
.0 \\
.0\end{array}$ & $\begin{array}{r}19 \\
2 . \\
5 .\end{array}$ & $\begin{array}{r}105 \\
24 \\
116\end{array}$ & $\begin{array}{l}238 \\
101 \\
599\end{array}$ \\
\hline $\begin{array}{l}\text { July } \\
\text { August } \\
\text { September }\end{array}$ & $\begin{array}{l}418 \\
635 \\
685\end{array}$ & $\begin{array}{l}5,800 \\
8,400 \\
7,730\end{array}$ & $\begin{array}{l}.00 \\
3.3 \\
6.0\end{array}$ & $\begin{array}{l}8.0 \\
101 \\
124\end{array}$ & $\begin{array}{r}68 \\
211 \\
247\end{array}$ & $\begin{array}{l}200 \\
444 \\
470\end{array}$ & $\begin{array}{l}507 \\
836 \\
833\end{array}$ & $\begin{array}{l}1,190 \\
1,424 \\
1,449\end{array}$ \\
\hline $\begin{array}{l}\text { October } \\
\text { November } \\
\text { December }\end{array}$ & $\begin{array}{r}380 \\
84 \\
66\end{array}$ & $\begin{array}{r}4,730 \\
1,110 \\
880\end{array}$ & $\begin{array}{l}1.7 \\
.01 \\
.00\end{array}$ & $\begin{array}{r}36 \\
4.5 \\
1.8\end{array}$ & $\begin{array}{l}80 \\
18 \\
7.3\end{array}$ & $\begin{array}{r}178 \\
50 \\
25\end{array}$ & $\begin{array}{r}466 \\
109 \\
68\end{array}$ & $\begin{array}{l}972 \\
188 \\
178\end{array}$ \\
\hline All days & 245 & 8,400 & .00 & .2 & 8.9 & 72 & 274 & 689 \\
\hline
\end{tabular}


and transpiration in Lower Myakka Lake. During May, discharge at the control was estimated to be $0 \mathrm{ft}^{3} / \mathrm{s}$ about 50 percent of the time. For all days, discharge was less than 8.7 $\mathrm{ft}^{3} / \mathrm{s} 25$ percent of the time.

Runoff data from the long-term station near Sarasota can be used to estimate basin runoff from the $349-\mathrm{mi}^{2}$ drainage area downstream from the control near Laurel (table 6). Annual runoff at the long-term station ranged from 4.4 inches during water year 1956 to 34.3 in. during water year 1959. Fifty percent of the time, runoff at the station equaled or exceeded $13.3 \mathrm{in}$. per water year (median runoff). Runoff downstream from the control near Laurel would have produced an average equivalent discharge of about $110 \mathrm{ft}^{3} / \mathrm{s}$ in 1956 and about $860 \mathrm{ft}^{3} / \mathrm{s}$ in 1959 . Based on a median runoff of 13.3 in. per water year, the drainage area downstream from the control near Laurel would contribute an average of about $335 \mathrm{ft}^{3} / \mathrm{s}$ of freshwater inflow along the tidal reach. The distribution of runoff, however, is not uniform. For example, in 1947, 84 percent of the runoff occurred during the 3 months of July, August, and September as a result of thunder- storms and tropical disturbances. Conversely, in water year 1958,70 percent of the runoff occurred between October and March. In 1982, 44 percent of the runoff occurred during what is normally the dry season (April-June), largely because of an early season, unnamed tropical storm.

\section{Tides}

Astronomical tides can be categorized into the following types: (1) diurnal, (2) semidiurnal, and (3) mixed (Marmer, 1951). The type of tide varies with location; it also may vary periodically with time at any given location. During a diurnal tide, there is one high and one low water level during a tidal day (24 hours and 50 minutes). During a semidiurnal cycle, there are two highs and two lows per tidal day, with little difference between the corresponding tides on any given day. A mixed tidal cycle also has two highs and two lows, but there is a marked disparity between the heights of the corresponding tides. In a mixed type of tide, the highs and lows are differentiated as:

Table 5. Estimated duration analyses of streamflow at the Myakka River at the control near Laurel (station 02298880)

[Derived from equation 1]

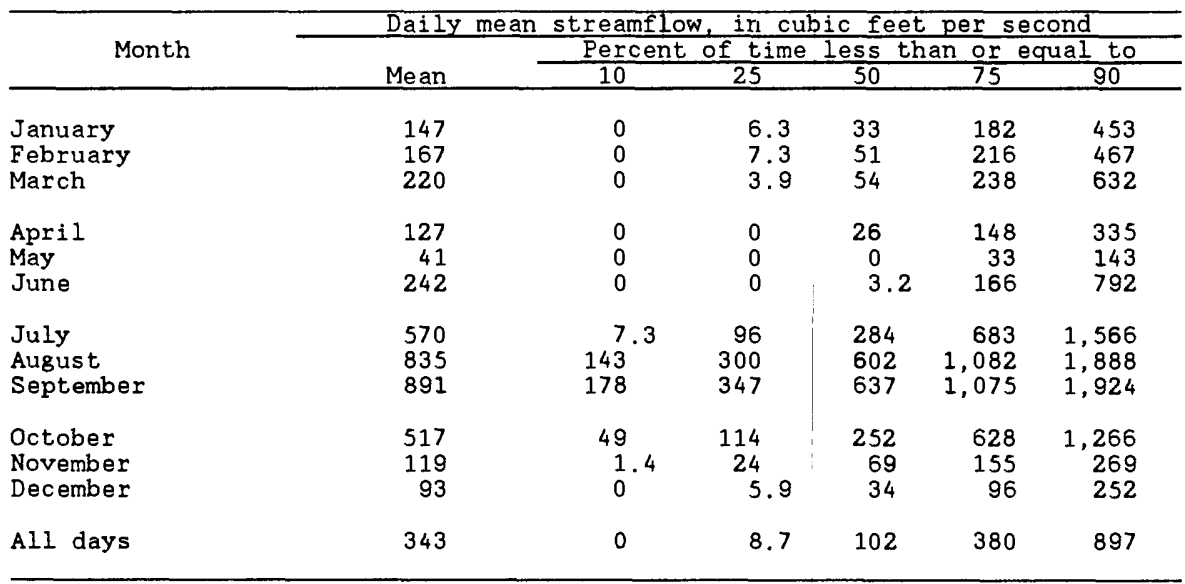

Table 6. Characteristics of runoff in the Myakka River basin $\left[\mathrm{mi}^{2}\right.$, square miles; $\mathrm{ft}^{3} / \mathrm{s}$, cubic feet per second; period of record, 1937-87]

\begin{tabular}{|c|c|c|c|}
\hline & $\begin{array}{l}\text { Runoff } \\
\text { near Sa } \\
\text { Inches }\end{array}$ & $\begin{array}{l}\text { Tyakka River } \\
\text { ta }(02298830) \\
\text { Water year }\end{array}$ & $\begin{array}{c}\text { Equivalent flow from ungaged } \\
349 \mathrm{mi}^{2} \text { of }_{3} \text { river basin } \\
\text { (ft } 3 \text { (s) }\end{array}$ \\
\hline \multicolumn{4}{|l|}{ Annual } \\
\hline $\begin{array}{l}\text { Maximum } \\
\text { Minimum } \\
\text { Median }\end{array}$ & $\begin{array}{r}34.3 \\
4.4 \\
13.3\end{array}$ & $\begin{array}{l}1959 \\
1956\end{array}$ & $\begin{array}{l}860 \\
110 \\
335\end{array}$ \\
\hline \multicolumn{4}{|c|}{$\begin{array}{l}\text { April-June } \\
\text { (dry season) }\end{array}$} \\
\hline $\begin{array}{l}\text { Maximum } \\
\text { Minimum }\end{array}$ & $\begin{array}{l}8.1 \\
0\end{array}$ & $\begin{array}{c}1982 \\
1944,1946 \\
1950,1971\end{array}$ & $\begin{array}{r}205 \\
0\end{array}$ \\
\hline Median & .8 & & 20 \\
\hline \multicolumn{4}{|c|}{$\begin{array}{l}\text { July-September } \\
\text { (wet season) }\end{array}$} \\
\hline $\begin{array}{l}\text { Maximum } \\
\text { Minimum } \\
\text { Median }\end{array}$ & $\begin{array}{r}27.0 \\
1.8 \\
6.7\end{array}$ & $\begin{array}{l}1947 \\
1984\end{array}$ & $\begin{array}{r}675 \\
45 \\
170\end{array}$ \\
\hline $\begin{array}{l}\text { October-Ma } \\
\text { Maximum } \\
\text { Minimum } \\
\text { Median }\end{array}$ & $\begin{aligned} 13.8 \\
.21 \\
4.2\end{aligned}$ & $\begin{array}{l}1958 \\
1962\end{array}$ & $\begin{array}{r}345 \\
5 \\
105\end{array}$ \\
\hline
\end{tabular}


higher high, lower high, higher low, and lower low. The west coast of peninsular Florida, including Charlotte Harbor and the Myakka River, typically has a mixed type of tide.

The range of the tide at a given location is not constant, but varies from day to day. Tides rise higher and fall lower (spring tides) about the times of the new and full moons. The tides rise and fall least (neap tides) during the Moon's first and third quarters. When the Moon is in perigee, or nearest the Earth, the tides rise higher and fall lower. When the Moon is in apogee, or farthest from the Earth, the tides rise and fall least. When the Moon is nearest the Equator, the differences between the two highs or two lows are minimized. When the Moon is at its farthest declination, the differences between two highs or two lows are maximized.

Tides are predicted on the basis of astronomical factors, but they also are influenced by interacting meteorologic, hydraulic, and hydrologic factors, including wind, bottom friction, inertia, and the proximity and magnitude of freshwater inflow. Actual tides may vary substantially from predicted tides because of these interacting factors. Tidalstage characteristics were monitored continuously at three sites in the study reach. The observed characteristics were analyzed and are discussed in this section.

\section{Data Network}

Tidal-stage stations were installed on the Myakka River at El Jobean (fig. 2, station 7) and at Snook Haven (fig. 2, station 5) in 1983. The stage station near Laurel (fig. 2, station 3 ), installed in 1985 , was originally intended as a discharge station, but was converted to a stage-only station when it became apparent that the site was affected by tidal oscillations during most of the year. Stage was recorded at 15-minute intervals at the El Jobean and Snook Haven stations. Stage was recorded at 1-hour intervals at station 3 near Laurel and at station 2 at the upstream end of the tidal reach at the control. Miscellaneous discharge measurements have been made at station 3 near Laurel, and a stage-discharge rating was developed for station 2 at the control.

Typical tidal patterns for the Myakka River are shown in figures 3,4 , and 5 . These figures illustrate the mixed-type tide that is characteristic of the Myakka River, Charlotte Harbor, and Florida's southern gulf coast. There is about a 2.5-hour lag between high tide at El Jobean and high tide at Snook Haven. High tide at Laurel occurs about the same time as high tide at Snook Haven. There is about a 3-hour lag between low tide at El Jobean and Snook Haven and about another hour lag between low tide at Snook Haven and the station near Laurel. During periods of low flow, there is a pronounced tidal oscillation at Laurel. During medium flow conditions, only the effects of high tides are apparent in the stage record at Laurel. At the end of March 1987, there was a storm event that produced high freshwater inflow. The effects of high flow on tidal oscillation are very apparent in figure 5. At Snook Haven, tidal patterns are almost completely drowned out with the passage of the storm flow, and at Laurel, all tidal oscillation is gone.

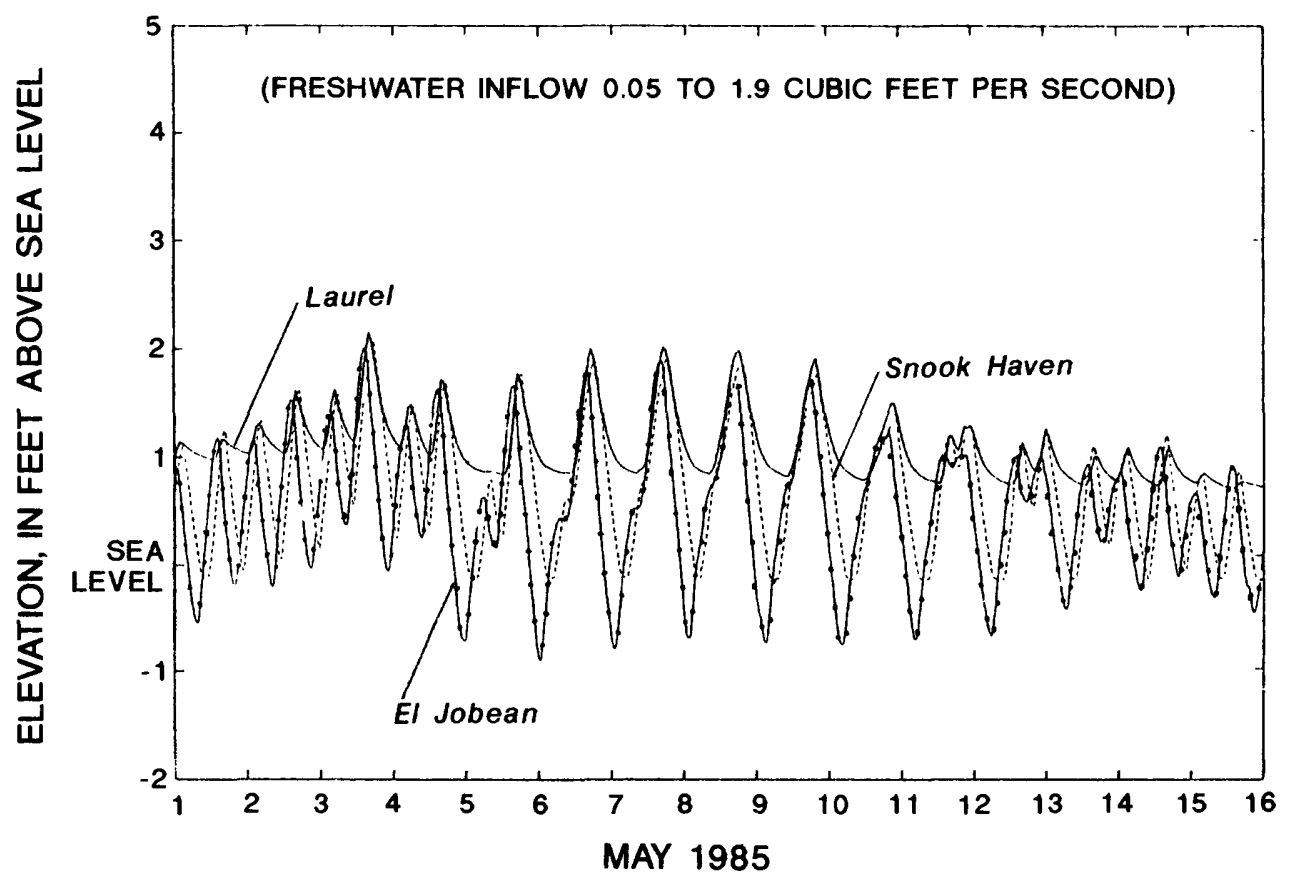

Figure 3. Typical tidal patterns associated with low freshwater inflow. 


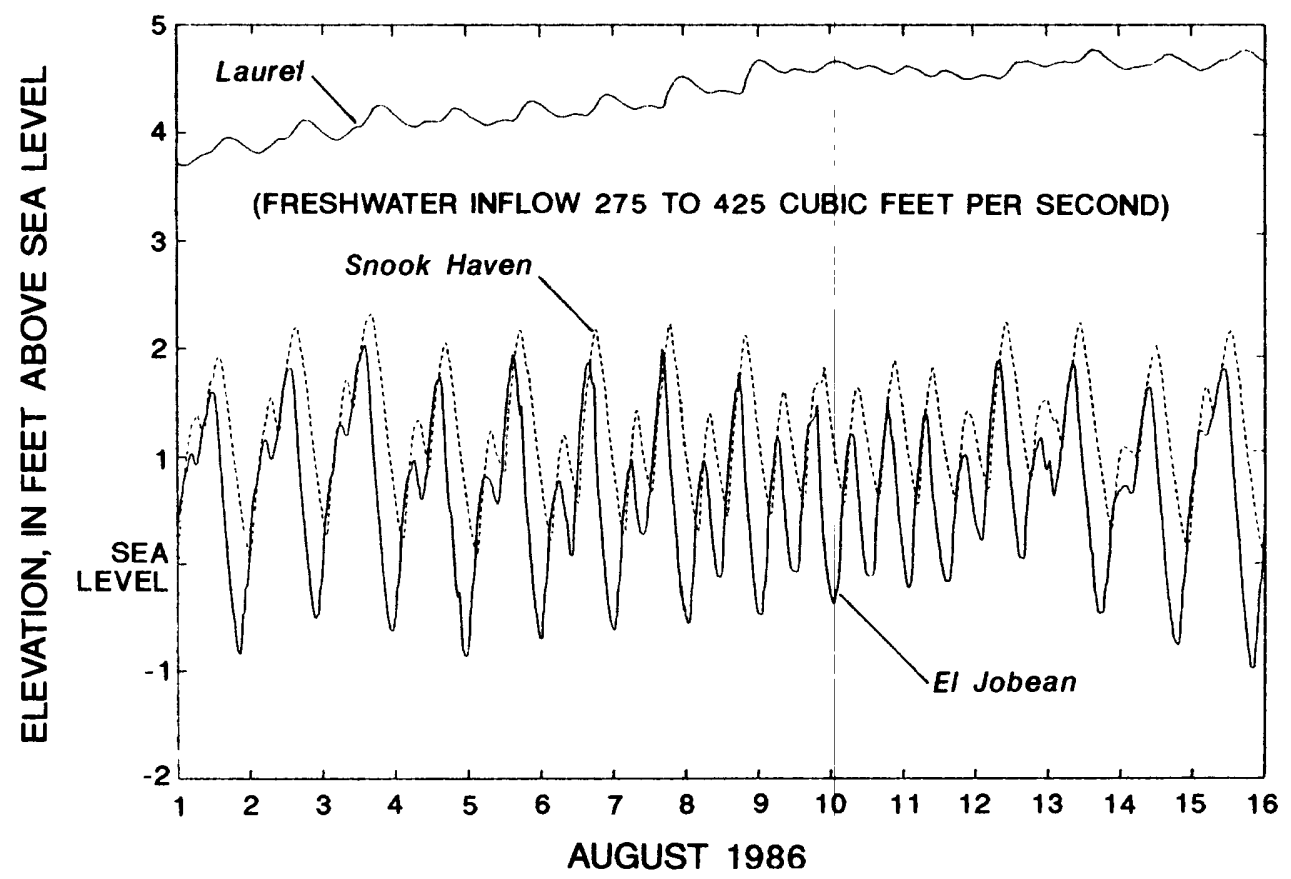

Figure 4. Typical tidal patterns associated with medium freshwater inflow.

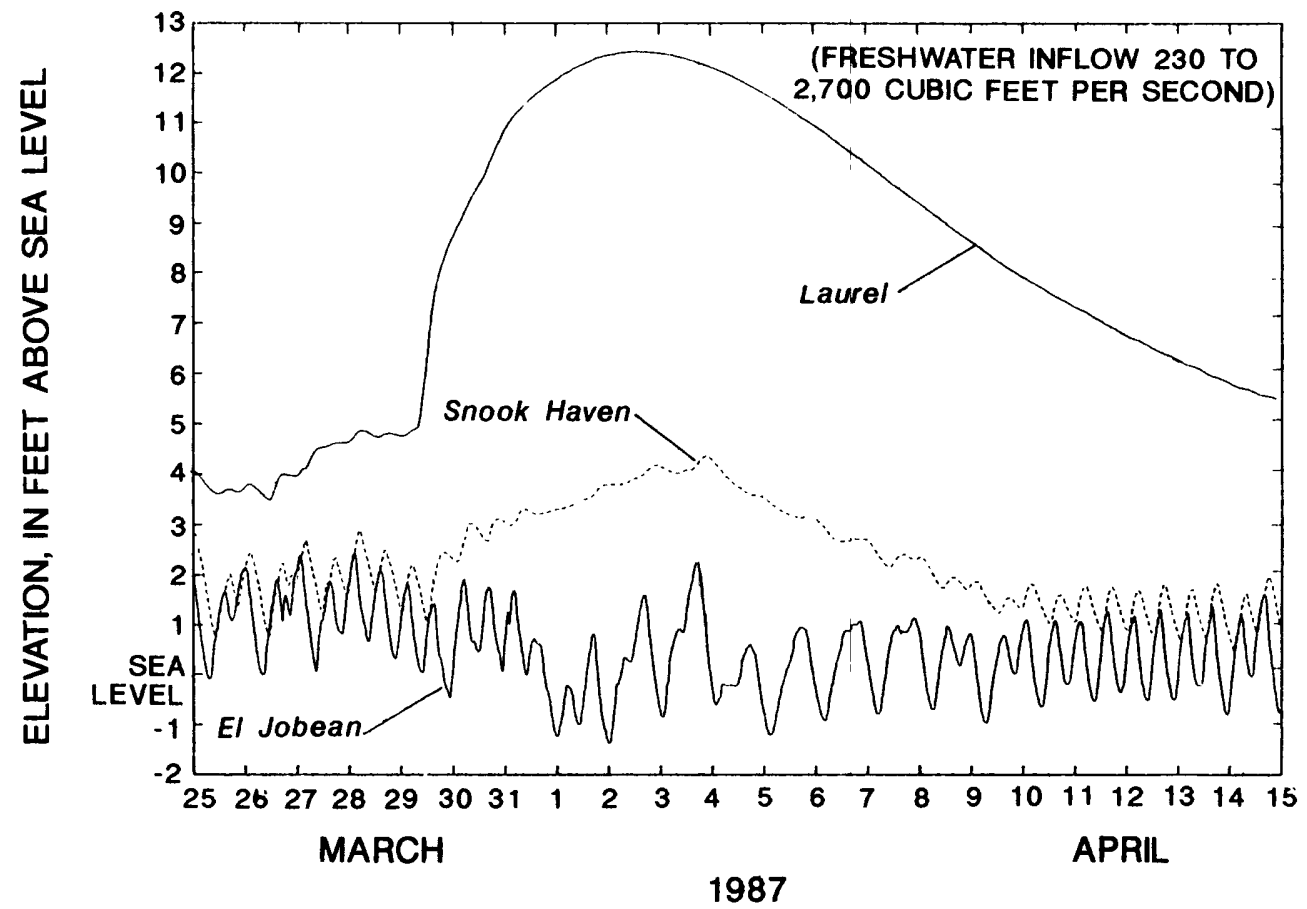

Figure 5. Typical tidal patterns associated with high freshwater inflow. 


\section{Tidal Range}

The tidal range is greater at El Jobean than at Snook Haven. Mean range at El Jobean was $2.20 \mathrm{ft}$ for the period of record. At Snook Haven, the mean range for the available period of record was $1.65 \mathrm{ft}$. During those times when the Laurel gage has a tidal oscillation, the tidal range averages about $0.45 \mathrm{ft}$. At El Jobean, the minimum and maximum recorded tidal ranges were $0.84 \mathrm{ft}$ and $4.23 \mathrm{ft}$, respectively; 5 percent of the time, the tidal range was greater than 2.88 $\mathrm{ft}$, and 5 percent of the time, it was less than $1.47 \mathrm{ft}$. At Snook Haven, the minimum recorded tidal range was 0.32 $\mathrm{ft}$ and the maximum was $3.58 \mathrm{ft}$; 5 percent of the time, the tidal range was greater than $2.25 \mathrm{ft}$, and 5 percent of the time, it was less than $0.98 \mathrm{ft}$. At Laurel, the tidal oscillation disappeared completely during high flows; the maximum recorded tidal range was $2.23 \mathrm{ft}$, but 75 percent of the time, the oscillation was less than $0.59 \mathrm{ft}$. Tidal backwater may produce a 0.1 - to $0.2-\mathrm{ft}$ oscillation in stage at the control near Laurel.

\section{Duration Analyses}

Duration analyses of daily maximum stages at the tidal station at the Myakka River at El Jobean (fig. 2, station 7) are shown, by month, and for the period of record in table 7. All stages are referenced to National Geodetic Vertical Datum of 1929, called sea level in this report. The highest daily maximum stage at the station occurred in August 1985 as Hurricane Elena passed offshore in the gulf. The median (50th percentile) daily maximum stage is $1.71 \mathrm{ft}$. Ninety percent of the time, the daily maximum stages were greater than $1.08 \mathrm{ft}$, and 10 percent of the time, they were greater than $2.21 \mathrm{ft}$. Only 5 percent of the time was the daily maximum stage greater than $2.38 \mathrm{ft}$. During the period of record, the highest tides tended to occur between August and November. During May when freshwater inflow is typically the lowest, the daily maximum stages averaged $1.61 \mathrm{ft}$, slightly less than the period-of-record mean.

\section{SALINITY CHARACTERISTICS}

The upstream movement of salty ocean water is driven by the tide and opposed by freshwater inflow. Depending on the relative magnitude of these factors, the river may become stratified because of the density differences between freshwater and saltwater. The degree of stratification is primarily dependent on the effects of buoyant and turbulent forces. Generally, high freshwater inflows increase buoyant forces and result in stratified conditions. Turbulent forces of wind and tide tend to increase mixing and result in partially mixed or well-mixed waters.

In a tidal reach that is highly stratified (fig. 6A), the freshwater tends to ride on top of the denser saltwater. Net velocity may be downstream at the surface and upstream at the bottom. At the boundary between the saltwater and freshwater is a zone of shear-induced, local, turbulent mixing that has a net upward circulation. Highly stratified conditions generally exist when freshwater inflow is large in relation to tidal flow.

Under partially mixed conditions (fig. 6B), neither buoyant nor turbulent forces dominate. Flow reversals generally occur at both the surface and the bottom during part of the tidal cycle. The transition from freshwater to saltwater occurs over a broad zone rather than at a sharp interface. Turbulent mixing is present over a wide area.

In a tidal reach that is well mixed (fig. 6C), there is almost no vertical variation in density, indicating that turbulent mixing predominates with little or no influence of

Table 7. Duration analyses of daily maximum stage at the Myakka River at El jobean (station 02299496)

[Period of record, October 1983-June 1987]

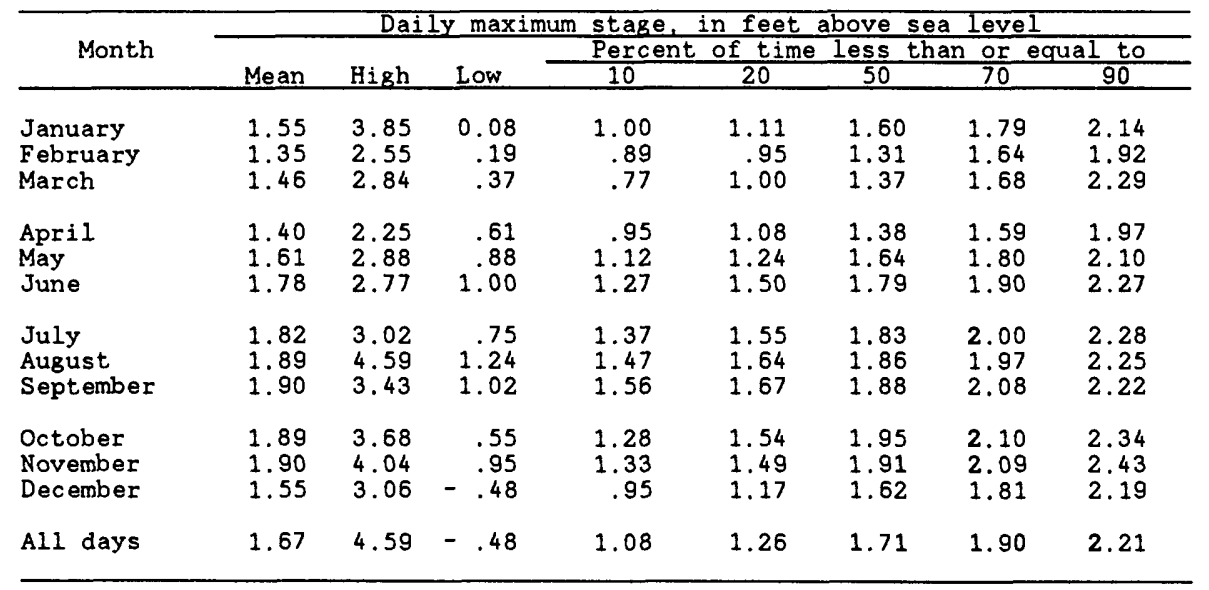


buoyant forces. In this situation, freshwater inflow is small in relation to tidal flow. At any given time, flow is unidirectional from top to bottom. The tidal reach of the Myakka River is normally well-mixed.

For purposes of this study, the transition from saltwater to freshwater was defined as the location of the vertically averaged 0.5 -ppt line of equal salinity. Salinity was calculated from specific conductance using equations from Miller and others (1988, p. 14). The transition from saltwater to freshwater was observed in the field as far upstream as about $4 \mathrm{mi}$ above Border Road and as far downstream as the bridge at El Jobean. Thus, during 1983-87, the location of the saltwater-freshwater interface ranged over a distance of more than 22 river miles in response to the relative magnitudes of tide and freshwater inflow.

\section{Data Network}

To continuously monitor salinity, specific-conductance monitors were installed near mid-depth on the Myakka River at El Jobean (fig. 2, station 7), North Port (fig. 2, station 6), and Snook Haven (fig. 2, station 5) in 1983. In 1986, a floating station was installed near Venice, just downstream from Border Road (fig. 2, station 4). Specific conductance at these monitoring stations was recorded at 15-minute intervals. Salinity was then calculated from specific-conductance measurements using the equations presented by Miller and others (1988, p. 14).

Typical salinity patterns associated with low, medium, and high freshwater inflows are shown in figures 7,8 , and 9. The time periods shown are the same as those used for illustrating tidal patterns in figures 3, 4, and 5 . During May 1-15, 1985 (fig. 7), freshwater inflow at the upstream end of the tidal reach is estimated to have been consistently less than $2.0 \mathrm{ft}^{3} / \mathrm{s}$. The saltwater-freshwater interface was upstream from Snook Haven for the entire period; at no time was salinity at Snook Haven less than 0.9 ppt. At North Port, salinity remained greater than $15 \mathrm{ppt}$, and at El Jobean, the salinity remained greater than $25 \mathrm{ppt}$.

During August 1-15, 1986 (fig. 8), freshwater inflow at the upstream end of the tidal reach ranged from 275 to 425 $\mathrm{ft}^{3} / \mathrm{s}$. Salinity at Snook Haven was less than $0.5 \mathrm{ppt}$ for the entire period. At North Port, salinity ranged from 0.3 to 1.0 ppt, and every day there was some freshwater flow at the site. Records for the station at El Jobean indicate that salinity ranged from 2.6 to $13.5 \mathrm{ppt}$ and averaged about $7.5 \mathrm{ppt}$ during this period of medium freshwater inflow.

A storm near the end of March 1987 (fig. 9) produced freshwater inflows greater than $2,500 \mathrm{ft}^{3} / \mathrm{s}$. As a result of runoff and high inflows, freshwater reached as far downstream as the station at El Jobean on March 31 and April 1. From March 30 to April 11, the salinity at North Port stayed constant at $0.3 \mathrm{ppt}$. At Snook Haven, salinity was constant at $0.1 \mathrm{ppt}$.

To complement data from the continuous recording station, vertical profiles of salinity were measured at more

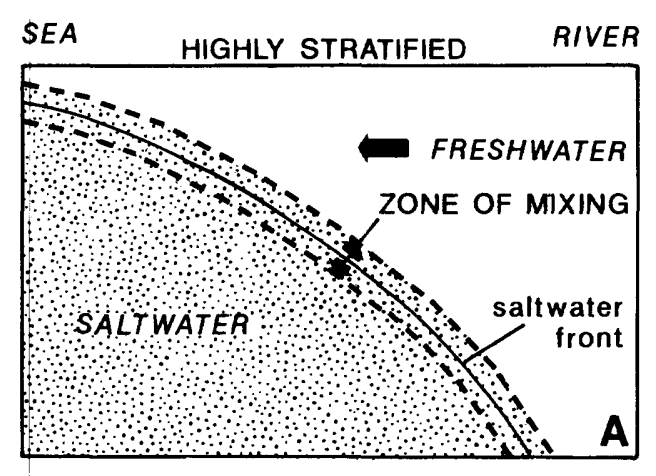

PARTIALLY MIXED

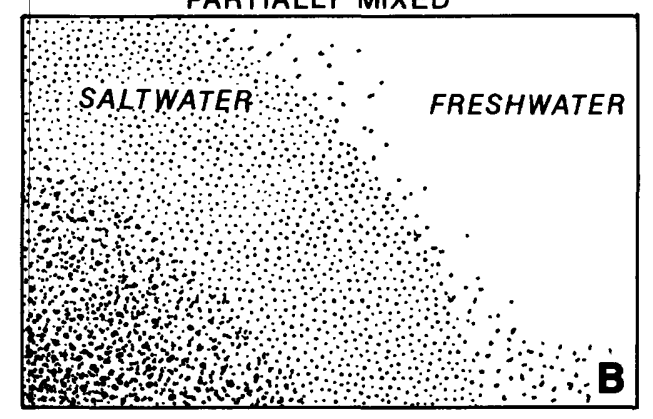

WELL MIXED

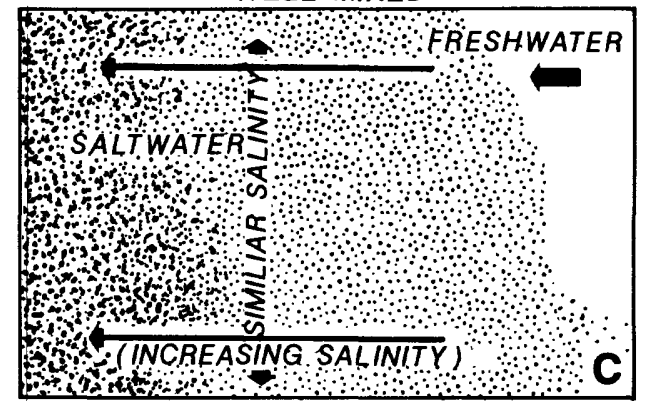

Figure 6. Highly stratified (A), partially mixed (B), and well mixed (C) conditions in the tidal reach.

than 40 locations along the tidal reach during various freshwater inflow conditions. Profiles were measured on 19 occasions between December 1982 and June 1987. Vertical profiles for the Myakka River at El Jobean (fig. 2, station 7) are presented in table 8 . The height of the tide at El Jobean and the streamflow at the upstream end of the tidal reach are shown for comparison. Figure 10 shows vertical profiles along the tidal reach that were measured during low, medium, and high freshwater inflow conditions.

\section{Salinity Range}

Selected percentiles of daily mean salinities along the tidal reach are listed in table 9 and shown graphically 


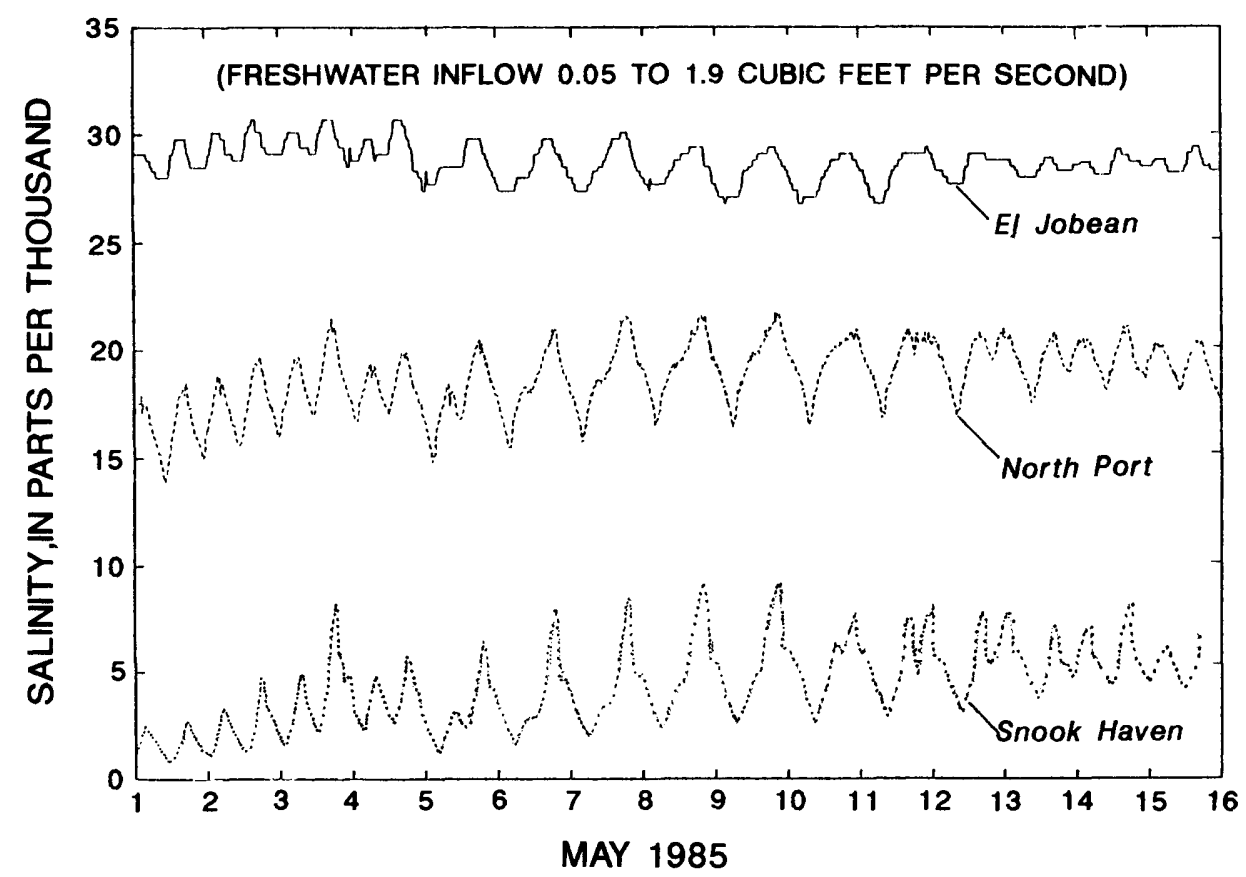

Figure 7. Typical salinity patterns associated with low freshwater inflow.

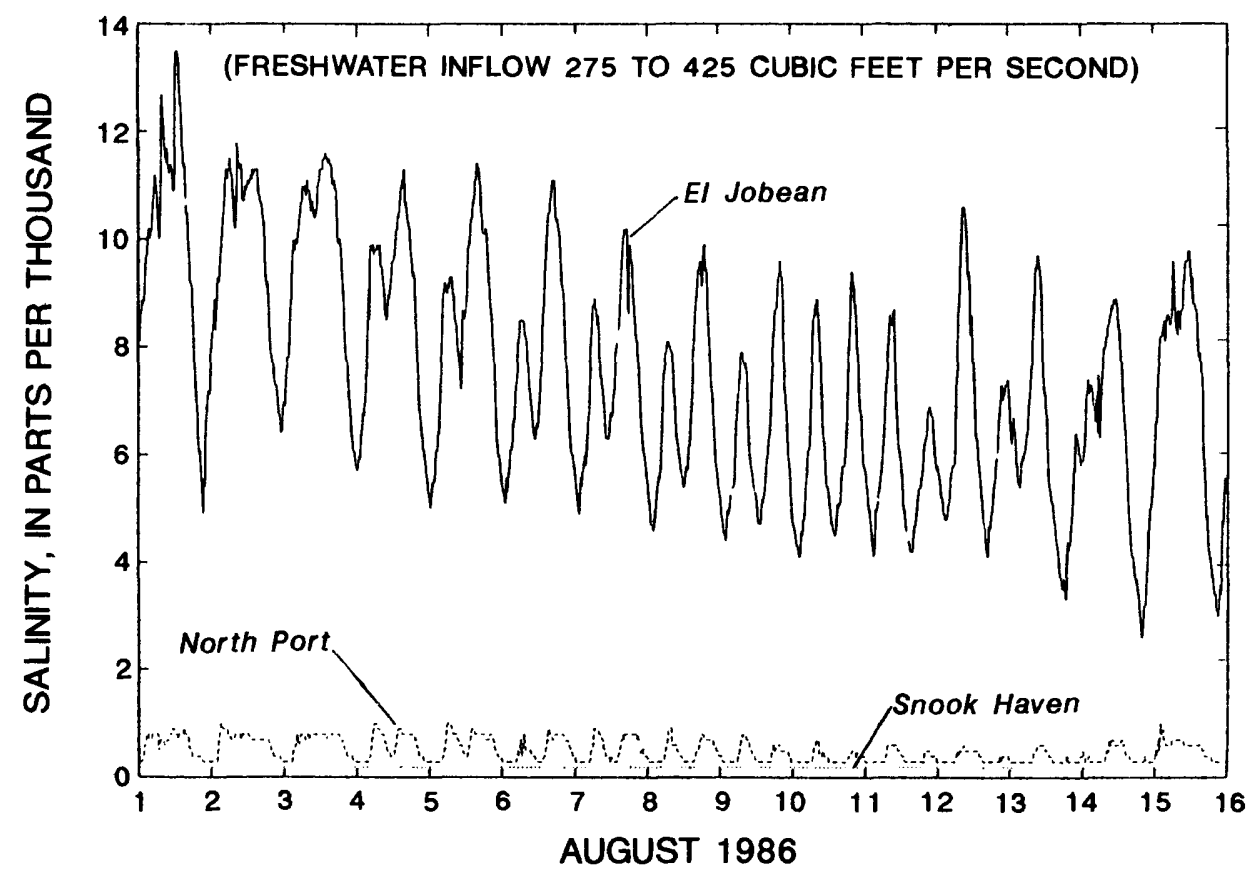

Figure 8. Typical salinity patterns associated with medium freshwater inflow. 


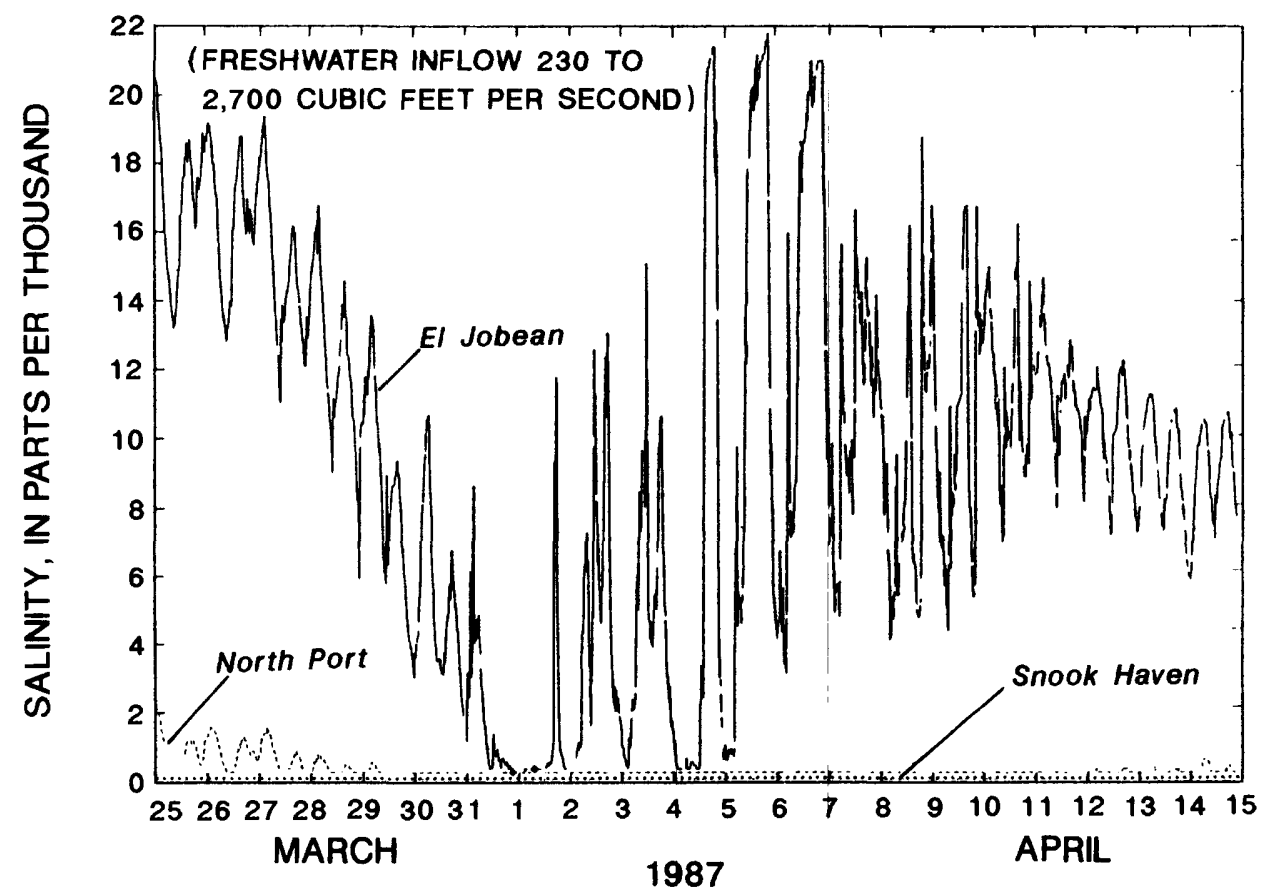

Figure 9. Typical salinity patterns associated with high freshwater inflow.

in figure 11. At the Myakka River at El Jobean (fig. 2, station .7), the average salinity during the period of record was 16.7 ppt. The maximum recorded salinity was $33 \mathrm{ppt}$ and the minimum was $0.4 \mathrm{ppt}$. The daily variation in salinity averaged $5.9 \mathrm{ppt}$, but on some days, the salinity remained fairly constant, and on a few days, the salinity varied more than 20 ppt.

At the station at U.S. Highway 41 near North Port (fig. 2, station 6), the average salinity during the period of record was $5.1 \mathrm{ppt}$. The minimum and maximum salinities recorded were 0.1 and $28.3 \mathrm{ppt}$. The daily variation in salinity averaged $2.7 \mathrm{ppt}$, but like the station at El Jobean, on some days, the salinity remained constant, and on a few days, it varied more than $15 \mathrm{ppt}$.

An extended period with no freshwater inflow during the spring of 1985 resulted in saltwater moving upstream from Snook Haven (fig. 2, station 5). From June 4 to July 14, 1985, daily mean salinity at Snook Haven exceeded $10 \mathrm{ppt}$ and dailymaximum salinities were as high as $17.1 \mathrm{ppt}$. The salinity patterns of 1985 tended to skew the data so that, even though the computed average salinity for the period of record was $0.91 \mathrm{ppt}$, the daily mean salinity at the station exceeded 0.2 ppt only 50 percent of the time (table 9). Seventy-five percent of the time, the daily variation in salinity was less than or equal to $0.2 \mathrm{ppt}$. Ten percent of the time, the salinity varied more than $2.1 \mathrm{ppt}$.

The floating gage near Border Road (fig. 2, station 4) was installed because of the high salinities recorded at Snook Haven during 1985. During a field survey in July 1985, salinity near Border Road was about 10 ppt. During the 1986 period of record at the gage, however, daily mean salinity exceeded 0.5 ppt only on 3 days, and the highest salinity recorded was $1.0 \mathrm{ppt}$.

\section{Duration Analyses}

Duration analyses of daily maximum salinities at the continuous-record stations are presented in tables 10 through 13 . The percentages of time that daily maximum salinities were less than or equal to given values are presented by month and for the period of record. The distribution of daily maximum salinities at El Jobean (table 10) and near Border Road (table 13) appear to be fairly symmetrical. At North Port (table 11) and Snook Haven Fish Camp (table 12), the means are higher than the medians, indicating skewed distributions that are affected by infrequent high salinities.

During the period of record at El Jobean, daily maximum salinity exceeded $11.9 \mathrm{ppt} 90$ percent of the time, and exceeded 28.3 ppt 10 percent of the time (table 10). At North Port, the daily maximum was greater than $1.0 \mathrm{ppt} 75$ percent of the time, but it was greater than $17.2 \mathrm{ppt}$ only 10 percent of the time (table 11 ). The daily maximum salinity at Snook Haven was less than 0.60 ppt 75 percent of the time (table 12); therefore, saltwater reached as far upstream as Snook Haven less than 25 percent of the time. Saltwater reached upstream to Border Road less than 5 percent of the time (table 13).

\section{Regression Analysis}

Data collected during the vertical-profile measurements (fig. 10) were used to produce a regression equation relating the farthest upstream incursion of the 0.5 -ppt line of equal salinity to the height of the applicable high tide at El Jobean and streamflow of the Myakka River at the control near Laurel. Of the 19 field surveys made between 1982 and 1987, 
Table 8. Vertical profiles of salinity near the Myakka River at El Jobean (station 02299496)

[ft ${ }^{3} / \mathrm{s}$, cubic feet per second; ppt, parts per thousand; --, no data]

\begin{tabular}{|c|c|c|c|c|}
\hline Date & $\begin{array}{c}\text { Streamflow } \\
\text { at the } \\
\text { control } \\
\text { near I } \text { taurel } \\
\text { (ft } / \mathrm{s})\end{array}$ & $\begin{array}{l}\text { Stage at } \\
\text { E1 Jobean } \\
\text { (feet above } \\
\text { sea level) }\end{array}$ & $\begin{array}{l}\text { Depth } \\
\text { (feet) }\end{array}$ & $\begin{array}{c}\text { Salinity } \\
\text { (ppt) }\end{array}$ \\
\hline $12 / 10 / 82$ & -- & $-\infty$ & $\begin{array}{r}1.0 \\
2.0 \\
4.0 \\
6.0 \\
8.0 \\
10.0 \\
12.0\end{array}$ & $\begin{array}{l}18.9 \\
19.0 \\
19.0 \\
19.0 \\
19.0 \\
19.1 \\
19.1\end{array}$ \\
\hline $02 / 16 / 84$ & 43 & -1.01 & $\begin{array}{r}1.0 \\
11.5\end{array}$ & $\begin{array}{l}11.5 \\
13.4\end{array}$ \\
\hline $03 / 21 / 84$ & 179 & .32 & $\begin{array}{r}1.0 \\
5.0 \\
10.0 \\
14.0\end{array}$ & $\begin{array}{l}5.5 \\
5.5 \\
6.7 \\
7.0\end{array}$ \\
\hline $05 / 11 / 84$ & 26 & .95 & $\begin{array}{r}1.0 \\
7.0 \\
13.0\end{array}$ & $\begin{array}{l}11.8 \\
11.8 \\
11.8\end{array}$ \\
\hline $06 / 13 / 84$ & 33 & 2.18 & $\begin{array}{r}1.0 \\
5.0 \\
10.0 \\
15.0\end{array}$ & $\begin{array}{l}15.9 \\
17.0 \\
17.2 \\
17.3\end{array}$ \\
\hline $07 / 09 / 84$ & 77 & 1.75 & $\begin{array}{r}1.0 \\
5.0 \\
10.0 \\
13.0\end{array}$ & $\begin{array}{l}16.0 \\
16.8 \\
16.9 \\
17.0\end{array}$ \\
\hline $08 / 28 / 84$ & 307 & -.03 & $\begin{array}{r}1.0 \\
5.0 \\
11.0\end{array}$ & $\begin{array}{l}5.8 \\
5.8 \\
6.5\end{array}$ \\
\hline $03 / 06 / 85$ & 3.25 & -1.02 & $\begin{array}{r}1.0 \\
5.0 \\
10.0\end{array}$ & $\begin{array}{l}23.4 \\
23.4 \\
23.4\end{array}$ \\
\hline $05 / 08 / 85$ & 1.8 & .83 & $\begin{array}{r}1.0 \\
5.0 \\
12.0\end{array}$ & $\begin{array}{l}28.0 \\
28.0 \\
28.0\end{array}$ \\
\hline $06 / 04 / 85$ & .00 & -- & \multicolumn{2}{|c|}{ Not measured } \\
\hline $07 / 16 / 85$ & .45 & 1.86 & $\begin{array}{r}1.0 \\
6.0 \\
14.0\end{array}$ & $\begin{array}{l}30.6 \\
30.6 \\
30.8\end{array}$ \\
\hline $09 / 24 / 85$ & 403 & 1.81 & $\begin{array}{r}1.0 \\
5.0 \\
9.0 \\
15.0\end{array}$ & $\begin{array}{l}11.5 \\
12.3 \\
17.9 \\
18.6\end{array}$ \\
\hline $04 / 24 / 86$ & 50 & 1.28 & $\begin{array}{r}1.0 \\
2.0 \\
4.0 \\
6.0 \\
8.0 \\
10.0 \\
11.0\end{array}$ & $\begin{array}{l}23.0 \\
23.1 \\
23.2 \\
23.2 \\
23.3 \\
23.3 \\
23.3\end{array}$ \\
\hline $05 / 22 / 86$ & 16 & 2.05 & $\begin{array}{r}1.0 \\
2.0 \\
4.0 \\
6.0 \\
8.0 \\
10.0\end{array}$ & $\begin{array}{l}24.5 \\
24.6 \\
24.6 \\
24.6 \\
24.7 \\
24.7\end{array}$ \\
\hline $09 / 16 / 86$ & 877 & 2.11 & $\begin{array}{r}1.0 \\
2.0 \\
4.0 \\
6.0 \\
8.0 \\
10.0 \\
11.0\end{array}$ & $\begin{array}{l}7.2 \\
7.2 \\
7.2 \\
7.2 \\
7.3 \\
7.3 \\
7.3\end{array}$ \\
\hline
\end{tabular}

Table 8. Vertical profiles of salinity near the Myakka River at El lobean (station 02299496)-Continued

\begin{tabular}{|c|c|c|c|c|}
\hline Date & $\begin{array}{c}\text { Streamflow } \\
\text { at the } \\
\text { control } \\
\text { near taure1 } \\
\text { (ft } / \mathrm{s})\end{array}$ & $\begin{array}{l}\text { Stage at } \\
\text { El Jobean } \\
\text { (feet above } \\
\text { sea level) }\end{array}$ & $\begin{array}{l}\text { Depth } \\
\text { (feet) }\end{array}$ & $\begin{array}{l}\text { Salinity } \\
\text { (ppt) }\end{array}$ \\
\hline $10 / 14 / 86$ & 99 & 2.07 & $\begin{array}{r}1.0 \\
2.0 \\
4.0 \\
6.0 \\
8.0 \\
10.0 \\
12.0\end{array}$ & $\begin{array}{l}15.6 \\
15.6 \\
15.6 \\
15.6 \\
15.6 \\
15.7 \\
15.8\end{array}$ \\
\hline $04 / 24 / 87$ & 167 & .89 & $\begin{array}{l}1.0 \\
2.0 \\
4.0 \\
6.0 \\
8.0\end{array}$ & $\begin{array}{l}13.2 \\
14.7 \\
14.7 \\
14.7 \\
14.7\end{array}$ \\
\hline $05 / 14 / 87$ & 42 & 1.57 & $\begin{array}{r}1.0 \\
2.0 \\
4.0 \\
6.0 \\
8.0 \\
10.0 \\
12.0 \\
14.0\end{array}$ & $\begin{array}{l}17.2 \\
17.2 \\
17.2 \\
17.3 \\
17.3 \\
17.3 \\
17.3 \\
17.3\end{array}$ \\
\hline $06 / 11 / 87$ & 220 & 2.27 & $\begin{array}{r}1.0 \\
2.0 \\
4.0 \\
6.0 \\
8.0 \\
10.0 \\
12.0 \\
13.0\end{array}$ & $\begin{array}{l}17.2 \\
17.2 \\
17.4 \\
17.4 \\
17.6 \\
17.6 \\
17.6 \\
17.7\end{array}$ \\
\hline
\end{tabular}

only 11 could be used in development of the regression equation. One field survey was made in 1982, prior to installation of the tide gage at El Jobean. Four of the surveys were made in conjunction with general water-quality sampling in Charlotte Harbor and did not locate the farthest upstream incursion of the 0.5-ppt line of equal salinity. During three field surveys in 1985 , it was not possible to navigate far enough upstream to locate the transition zone.

The regression analysis is subject to limitations. The accuracy of the analysis is limited by the assumption that a steady-state or equilibrium condition has been reached between freshwater inflow, tidal stage, and salinity during the time of the field measurements. The regression analysis is representative of the hydrodynamic configuration that existed during the 1983-87 study period. If there is a modification in the control structure at the upstream end of the tidal reach, or if the channel configuration is changed by water-front construction, then the regression equation may no longer be applicable.

Equation 3, below, defines the relation of the farthest upstream movement of saltwater to high tide and freshwater inflow. The equation was developed using freshwater inflows ranging from 3.25 to $877 \mathrm{ft}^{3} / \mathrm{s}$, high tides at El Jobean ranging from 0.57 to $2.27 \mathrm{ft}$ above sea level, and the farthest upstream movement of saltwater ranging from 9.55 


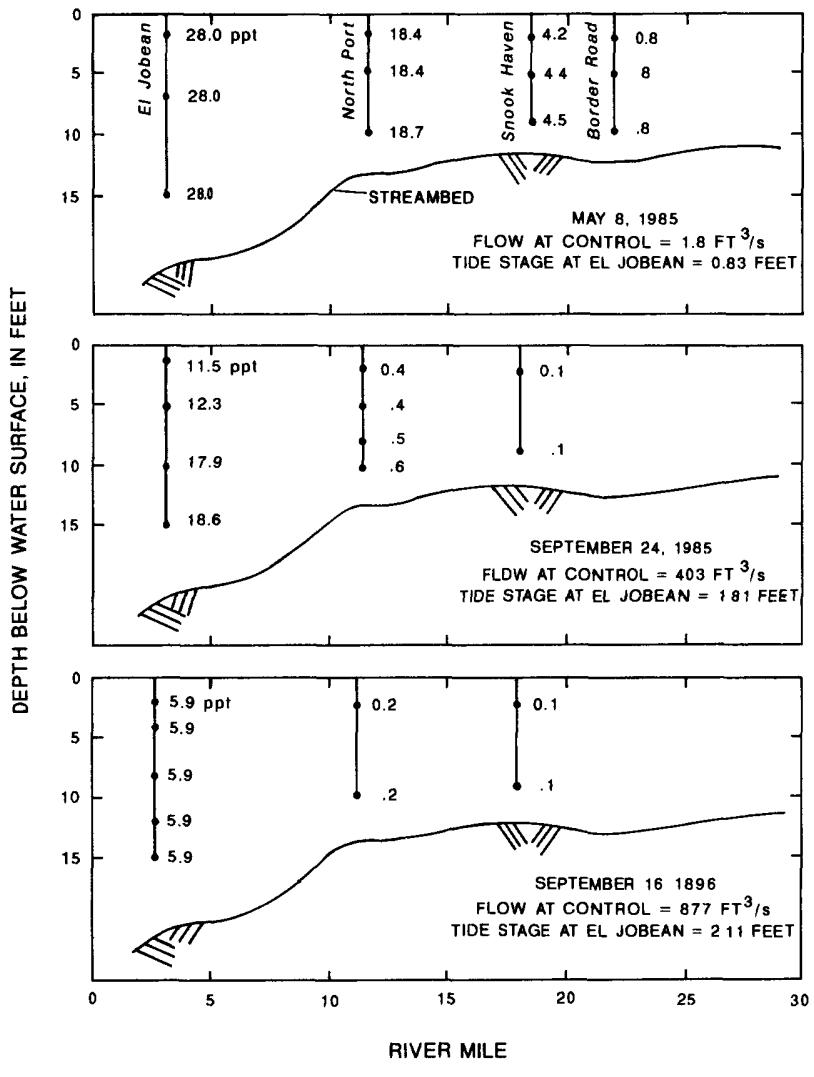

Figure 10. Vertical profiles of salinity at selected locations during low, medium, and high freshwater inflow.

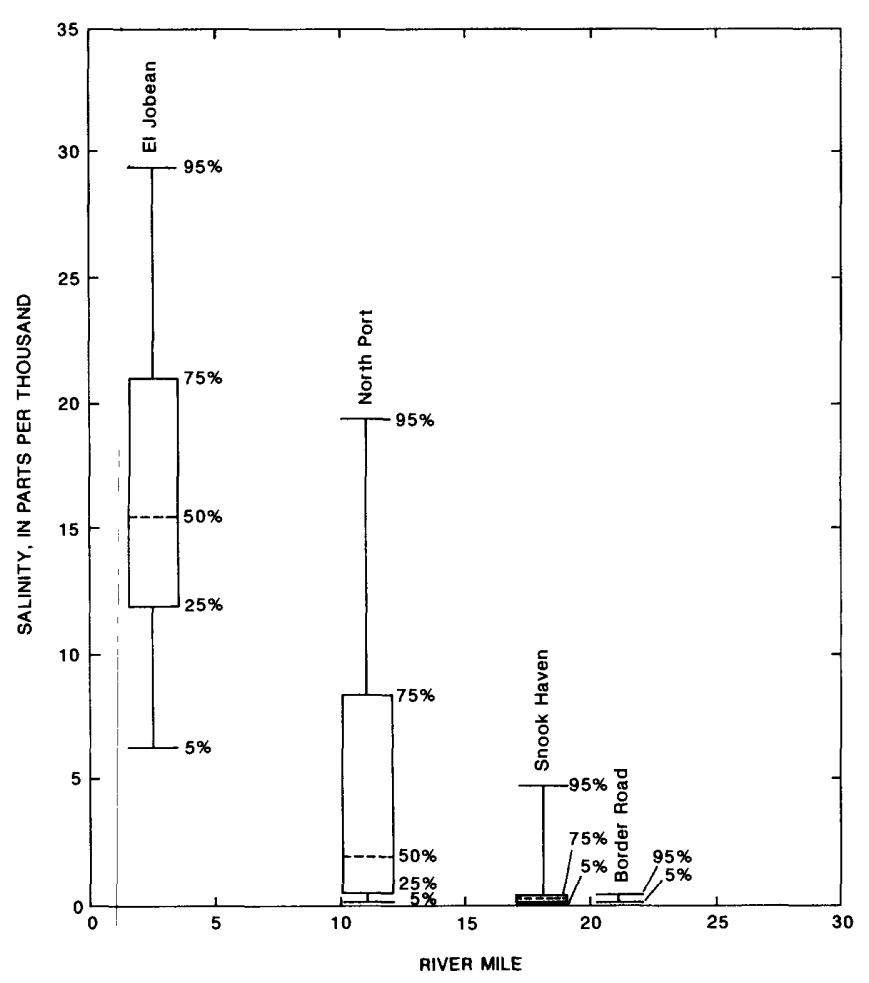

Figure 11. Percentiles of daily mean salinities along the tidal reach.

Table 9. Percentiles of daily mean salinities at stations along the tidal reach

\begin{tabular}{cccccc}
\hline \multirow{2}{*}{ Percentile } & \multicolumn{5}{c}{ Daily mean salinity, in parts per thousand, } \\
at indicated & station \\
\cline { 2 - 5 } & E1 Jobean & North Port & Snook Haven & Border Road \\
\hline 5 & 6.4 & 0.2 & 0.1 & 0.1 \\
10 & 8.3 & .3 & .1 & .1 \\
25 & 12.1 & .6 & .1 & .1 \\
50 & 15.6 & 1.9 & .2 & .2 \\
75 & 21.1 & 8.4 & .4 & .2 \\
90 & 27.1 & 14.5 & 1.4 & .4 \\
95 & 29.5 & 19.4 & 4.9 & .4 \\
\hline
\end{tabular}

Table 10. Duration analyses of daily maximum salinity at the Myakka River at El Jobean (station 02299496)

[Period of record, October 1983-June 1987]

\begin{tabular}{|c|c|c|c|c|c|c|c|c|c|c|}
\hline \multirow{3}{*}{ Month } & \multicolumn{3}{|c|}{ Daily maxi } & salin & ity, & \multirow{2}{*}{\multicolumn{2}{|c|}{ in parts per }} & \multicolumn{2}{|c|}{ thousand } & \multirow{3}{*}{$\frac{\text { to }}{95}$} \\
\hline & & & & $\mathrm{Per}$ & cent & & & than & or equa & \\
\hline & Mean & High & Low & 5 & 10 & 25 & 50 & 75 & 90 & \\
\hline $\begin{array}{l}\text { January } \\
\text { February } \\
\text { March }\end{array}$ & $\begin{array}{l}22.8 \\
22.3 \\
21.1\end{array}$ & $\begin{array}{l}27.7 \\
28.3 \\
28.0\end{array}$ & $\begin{array}{r}11.8 \\
16.3 \\
6.6\end{array}$ & $\begin{array}{r}16.2 \\
17.6 \\
8.4\end{array}$ & $\begin{array}{l}17.6 \\
18.0 \\
10.5\end{array}$ & $\begin{array}{l}20.5 \\
18.9 \\
18.4\end{array}$ & $\begin{array}{l}24.0 \\
20.8 \\
20.5\end{array}$ & $\begin{array}{l}25.4 \\
26.5 \\
27.4\end{array}$ & $\begin{array}{l}26.3 \\
27.1 \\
27.5\end{array}$ & $\begin{array}{l}27.1 \\
27.8 \\
27.7\end{array}$ \\
\hline $\begin{array}{l}\text { April } \\
\text { May } \\
\text { June }\end{array}$ & $\begin{array}{l}20.0 \\
20.9 \\
21.8\end{array}$ & $\begin{array}{l}30.8 \\
31.9 \\
33.0\end{array}$ & $\begin{array}{l}10.1 \\
10.2 \\
11.4\end{array}$ & $\begin{array}{l}11.0 \\
10.5 \\
12.0\end{array}$ & $\begin{array}{l}12.0 \\
11.8 \\
12.2\end{array}$ & $\begin{array}{l}13.2 \\
14.9 \\
16.1\end{array}$ & $\begin{array}{l}15.7 \\
21.7 \\
20.8\end{array}$ & $\begin{array}{l}28.4 \\
28.9 \\
30.5\end{array}$ & $\begin{array}{l}29.8 \\
30.7 \\
31.9\end{array}$ & $\begin{array}{l}30.2 \\
31.4 \\
32.6\end{array}$ \\
\hline $\begin{array}{l}\text { July } \\
\text { August } \\
\text { September }\end{array}$ & $\begin{array}{l}21.4 \\
15.2 \\
13.9\end{array}$ & $\begin{array}{l}32.4 \\
28.2 \\
26.5\end{array}$ & $\begin{array}{l}8.9 \\
2.0 \\
6.8\end{array}$ & $\begin{array}{r}11.1 \\
3.7 \\
7.3\end{array}$ & $\begin{array}{r}12.2 \\
5.8 \\
8.3\end{array}$ & $\begin{array}{r}14.2 \\
9.4 \\
10.9\end{array}$ & $\begin{array}{l}17.9 \\
13.1 \\
13.4\end{array}$ & $\begin{array}{l}30.0 \\
22.1 \\
16.8\end{array}$ & $\begin{array}{l}31.7 \\
27.4 \\
20.2\end{array}$ & $\begin{array}{l}32.1 \\
27.7 \\
22.3\end{array}$ \\
\hline $\begin{array}{l}\text { October } \\
\text { November } \\
\text { December }\end{array}$ & $\begin{array}{l}17.0 \\
18.5 \\
19.5\end{array}$ & $\begin{array}{l}21.8 \\
25.2 \\
28.7\end{array}$ & $\begin{array}{l}10.2 \\
13.2 \\
11.6\end{array}$ & $\begin{array}{l}12.1 \\
14.8 \\
14.3\end{array}$ & $\begin{array}{l}13.0 \\
15.3 \\
15.7\end{array}$ & $\begin{array}{l}15.2 \\
16.7 \\
17.2\end{array}$ & $\begin{array}{l}17.5 \\
18.4 \\
19.2\end{array}$ & $\begin{array}{l}19.1 \\
20.2 \\
21.4\end{array}$ & $\begin{array}{l}19.6 \\
22.0 \\
23.9\end{array}$ & $\begin{array}{l}20.3 \\
22.9 \\
25.2\end{array}$ \\
\hline A11 days & 19.6 & 33.0 & 2.0 & 10.2 & 11.9 & 15.1 & 18.9 & 24.2 & 28.3 & 30.6 \\
\hline
\end{tabular}


Table 11. Duration analyses of daily maximum salinity at the Myakka River at North Port (station 02299230)

[Period of record, June 1983-June 1987]

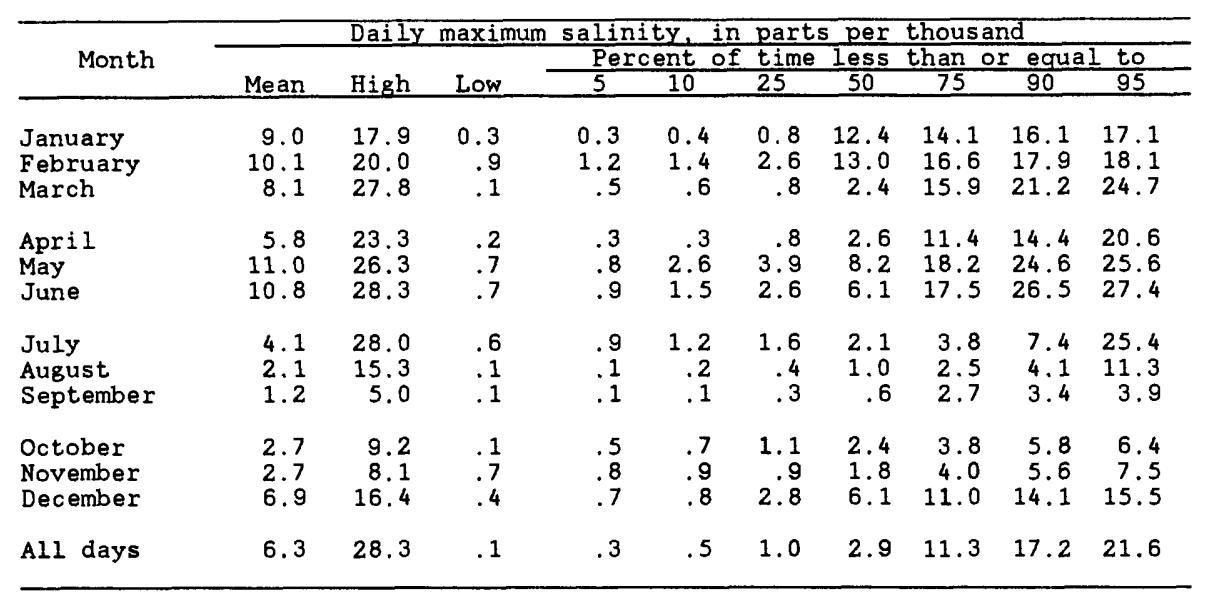

Table 12. Duration analyses of daily maximum salinity at the Myakka River at Snook Haven Fish Camp near Venice (station 02298955)

[Period of record, August 1983-June 1987]

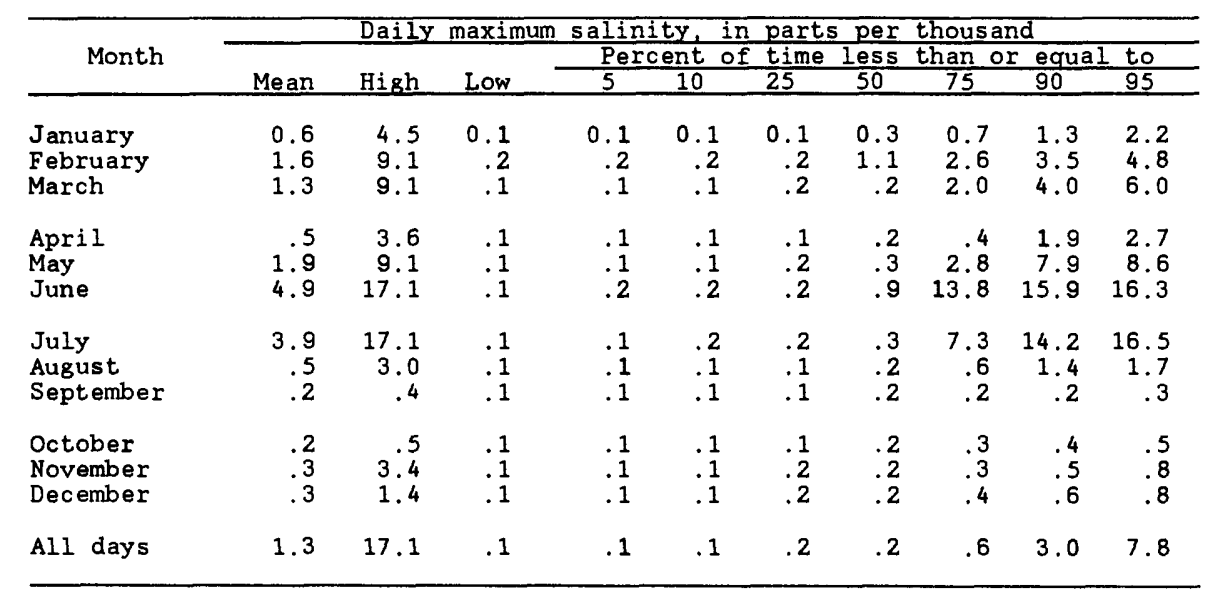

Table 13. Duration analyses of daily maximum salinity at the Myakka River near Venice (Border Road) (Station 02298930)

[Period of record, April-December 1986; --, no data]

\begin{tabular}{|c|c|c|c|c|c|c|c|c|c|c|}
\hline \multirow{2}{*}{ Month } & \multicolumn{10}{|c|}{ Daily maximum salinity, in parts per thousand } \\
\hline & Mean & High & Low & 5 & $\frac{\mathrm{ent}}{10}$ & 25 & 50 & $\frac{\cos 15}{75}$ & 90 & $\frac{10}{95}$ \\
\hline January & -- & -- & -- & -- & -- & -- & -- & -- & -- & -- \\
\hline February & -- & -- & -- & -- & -- & -- & -- & -- & -- & -- \\
\hline March & -- & -- & -- & -- & -- & -- & -- & -- & -- & -- \\
\hline April & 0.2 & 0.3 & 0.2 & 0.2 & 0.2 & 0.2 & 0.3 & 0.3 & 0.3 & 0.3 \\
\hline May & .3 & .4 & .2 & .2 & .2 & .2 & .3 & .3 & .3 & .4 \\
\hline June & .5 & 1.0 & .3 & .3 & .3 & .4 & .4 & .5 & .7 & .8 \\
\hline July & .2 & .3 & .2 & .2 & .2 & .2 & .2 & .2 & .3 & .3 \\
\hline August & .1 & .2 & .1 & .1 & .1 & .1 & .1 & .2 & .2 & .2 \\
\hline September & .1 & .1 & .1 & .1 & .1 & .1 & .1 & .1 & .1 & .1 \\
\hline October & .2 & .2 & .1 & .1 & .1 & & .1 & & & .2 \\
\hline November & .2 & .2 & .1 & .1 & .1 & .2 & .2 & .2 & .2 & .2 \\
\hline December & .2 & .2 & .2 & .2 & .2 & .2 & .2 & .2 & .2 & .2 \\
\hline All days & .2 & 1.0 & .1 & .1 & .1 & .1 & .2 & .3 & .4 & .5 \\
\hline
\end{tabular}


to 18.33 river miles above the mouth. The independent parameters are significant at the 1-percent level, the multiple correlation coefficient is 0.98 , and the standard error of estimate averages 4.6 percent.

$$
\text { RIVER MILE }=24.7913 * \mathrm{Q}^{-0.153} * \mathrm{TIDE}^{.160}
$$

where

RIVER MILE = location of the farthest upstream incursion of the 0.5 -ppt line of equal salinity, in river miles above Cattle Dock Point,

$\mathrm{Q}=$ daily mean freshwater inflow of the Myakka River at the control near Laurel, in cubic feet per second (from station record or estimated from equations 1 or 2), and TIDE $=$ height of the Japplicable high tide at the Myakka

River at El Jobean, in feet above sea level.

Equation 3 was used with observed tidal data at EI Jobean and freshwater inflow data at the Myakka River at the control near Laurel to produce an estimate of the farthest upstream incursion of the 0.5 -ppt line of equal salinity. Figure 12 shows results of that computation for each day during the period October 1983 to June 1987.

A duration analysis of the location of the farthest upstream movement of the 0.5 -ppt line of equal salinity during the period 1983 to 1987 also was derived from the application of equation 3. Results of that duration analysis are presented in table 14. The farthest upstream movement of the saltwater-freshwater interface typically occurs near river mile 14.0 , which is about 3 mi upstream from U.S. Highway 41. During the period of record, saltwater is believed to have encroached as far upstream as the control near Laurel, which, because of the control structure, serves as the maximum upstream limit of saltwater incursion. During high streamflow in April 1987, saltwater could not move upstream from river mile 7.0. About 10 percent of the time, the farthest incursion was downstream from river mile 10.6 , and about 10 percent of the time, it was upstream from river mile 19.3.

\section{POTENTIAL SALINITY CHANGES DUE TO FRESHWATER WITHDRAWALS}

Regression equation 3 was used with observed tidal data at El Jobean and reduced freshwater inflow to evaluate the change in salinity that could result from each of three different levels of freshwater diversion from the Myakka River. Dames and Moore, Inc. (1985), analyzed the economic and supply feasibility of withdrawing as much as 25 percent of the total available flow of the Myakka River at the upstream border of the Ringling-MacArthur Reserve. (Current regulations of the Southwest Florida Water Management District would not allow total withdrawals to reduce the rate of daily flow by more than 10 percent at any point in the drainage system at the time of withdrawal). In this study, diversions of 5, 10, and 25 percent were evaluated based on two constraints:
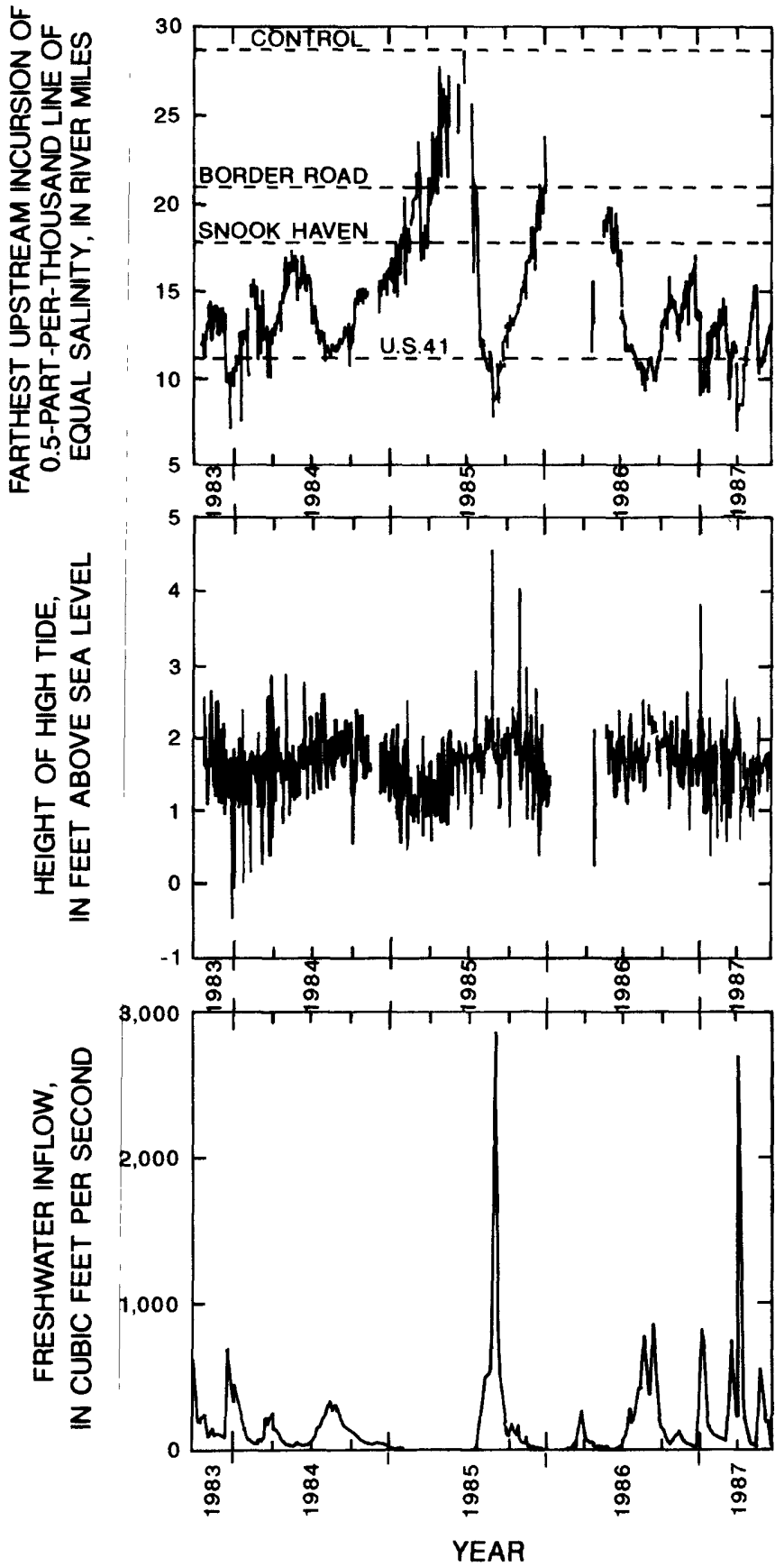

Figure 12. Freshwater inflow and high tide, and location of 0.5 -part-per-thousand line of equal salnity computed from regression equation.

1. Regulatory minimum flows were maintained, as defined by the following Southwest Florida Water Management District rule (Chapter 40D-8.041): "Minimum rates of flow shall be established as follows: For each month, the five (5) lowest monthly mean discharges for the preceding twenty (20) years shall be averaged. Minimum rates of flow shall be established as seventy percent $(70 \%)$ of these values for the four (4) wettest months and ninety percent $(90 \%)$ of these values for 
Table 14. Duration analyses of farthest upstream movement of the 0.5-part-per-thousand line of equal salinity, 1983-87

[ppt, part per thousand]

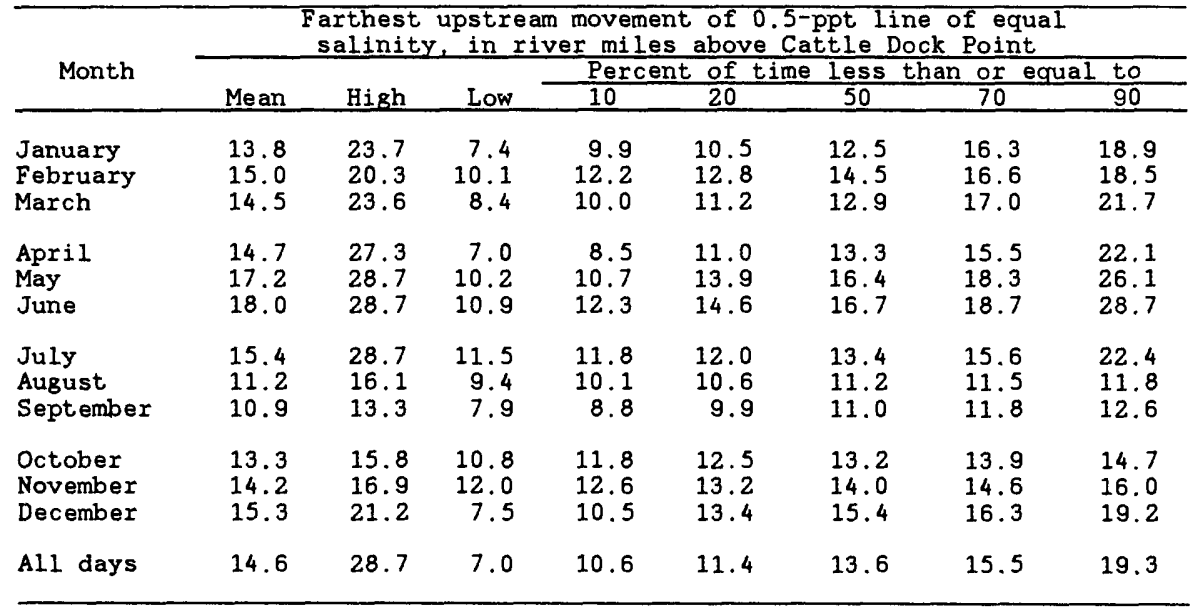

the remaining eight (8) months. The determination shall be based on available data, or in the absence of such data, it shall be established by reasonable calculations approved by the Board."

2. A maximum withdrawal capacity of $100 \mathrm{ft}^{3} / \mathrm{s}$ (based on pipe sizes from Dames and Moore, Inc., 1985) was maintained.

A diversion of 5 percent of freshwater flow at the control near Laurel, in conjunction with maintaining minimum monthly regulatory flows, as defined above, would conform to all current (1990) regulations of the Southwest Florida Water Management District. At this level of diversion, the computed location of the farthest incursion of the 0.5-ppt line of equal salinity would move an average of $0.1 \mathrm{mi}$ upstream and a maximum of $0.3 \mathrm{mi}$ upstream, based on data from the 1983-87 period of record. This computed upstream movement of the saltwater-freshwater interface is smaller than the 4.6 percent standard error of estimate of the regression equation. Based on the 1983-87 period, the volume of water supplied would average $5.4 \mathrm{Mgal} / \mathrm{d}$, but most of the diversion would have to occur in August and September. During 5 months of the year, less than $3 \mathrm{Mgal} / \mathrm{d}$ could be diverted.

A diversion of 10 percent of freshwater flow is the maximum that could be allowed under current Water Management District regulations. At a diversion level of 10 percent, the farthest incursion of the 0.5 -ppt line of equal salinity would move upstream an average of $0.2 \mathrm{mi}$ and a maximum of $0.7 \mathrm{mi}$, which is also generally smaller than the standard error of estimate of the regression equation. Based on the 1983-87 period, an average of about $10 \mathrm{Mgal} / \mathrm{d}$ could be supplied at this level, with most of the diversion occurring in August and September. During 4 months of the year, less than $5 \mathrm{Mgal} / \mathrm{d}$ could be diverted.

A diversion of 25 percent would be more than existing regulations allow. Under this level of withdrawal, the farthest incursion of the 0.5 -ppt line of equal salinity would move upstream an average of $0.6 \mathrm{mi}$ and a maximum of $1.9 \mathrm{mi}$, which is greater than the standard error of estimate of the regression equation. Based on the 1983-87 period, about 20 $\mathrm{Mgal} / \mathrm{d}$ could be supplied on the average with this level of diversion. Largest withdrawals would have to occur in August and September. During 2 months, less than 10 $\mathrm{Mgal} / \mathrm{d}$ could be withdrawn.

\section{SUMMARY}

The Myakka River basin drains $602 \mathrm{mi}^{2}$ in west-central Florida. The river is one of the three main tributaries to Charlotte Harbor. Sarasota County is evaluating the Myakka River as a potential source of water for municipal supply. Reducing freshwater inflow to the tidal reach of the Myakka River could alter salinity patterns in the reach, affecting the ecosystem. To evaluate the potential effects on the system, the relation between freshwater inflow, tide, and salinity must be understood.

In the Myakka River, freshwater inflow has a skewed distribution. Mean streamflow at the upstream end of the tidal reach averaged about $340 \mathrm{ft}^{3} / \mathrm{s}$, but median flow was $102 \mathrm{ft}^{3} / \mathrm{s}$. Twenty-five percent of the time, freshwater inflow at the upstream end of the tidal reach was less than or equal to 8.7 $\mathrm{ft}^{3} / \mathrm{s}$. There is a 20-percent chance that there will be no flow for 90 consecutive days in any year. 
At the downstream end of the tidal reach, the daily range in stage averaged about $2.20 \mathrm{ft}$. Daily maximum stage reached about $1.7 \mathrm{ft}$ above sea level, on the average. During periods of low flow, backwater effects from tide were observed as far as $28.7 \mathrm{mi}$ upstream from the mouth. Near the upstream end of the tidal reach, the tidal range was lower. During periods of average and high flow, the tidal oscillation disappeared completely at the upstream end.

The tidal reach of the Myakka River is normally well mixed. Stratification occurs only during periods of high flow. At El Jobean, salinity averaged 16.7 ppt. At U.S. Highway 41 (near North Port), salinity averaged 5.1 ppt. There was no daily variation in salinity at Snook Haven Fish Camp about 50 percent of the time. Following an extended period of very low streamflow in 1985, salinity exceeded 15 ppt at Snook Haven and exceeded $10 \mathrm{ppt}$ at the bridge on Border Road.

The location of the farthest upstream incursion of saltwater, defined as the 0.5-ppt line of equal salinity, was estimated by regression analysis as a function of freshwater inflow and height of high tide. During the period of record from 1983-87, the farthest incursion of the 0.5-ppt line of equal salinity averaged about $14 \mathrm{mi}$ upstream from Cattle Dock Point. On some days, saltwater is estimated to have reached the control near Laurel. Saltwater reached at least as far as river mile 7.0 every day during the period of record.

Reducing freshwater inflow by 5 percent and maintaining regulatory minimum monthly flows would result in the 0.5-ppt line of equal salinity moving upstream an average of $0.1 \mathrm{mi}$. A 10-percent diversion of freshwater would result in saltwater moving upstream an average of $0.2 \mathrm{mi}$ and a maximum of $0.7 \mathrm{mi}$. Diverting 25 percent of freshwater at the upstream end of the tidal reach, which would exceed current regulatory limits, would allow the 0.5 -ppt line of equal salinity to move upstream an average of $0.6 \mathrm{mi}$ and a maximum of $1.9 \mathrm{mi}$.

\section{SELECTED REFERENCES}

Bureau of Economic and Business Research, 1985, Florida estimates of population: Gainesville, University of Florida College of Business Administration.

Dames and Moore, Inc., 1985, Preliminary options report, water supply development project, Ringling-MacArthur Reserve: Engineering consultant's report to Sarasota County, $55 \mathrm{p}$.

Flippo, H.N., Jr., and Joyner, B.F., 1968, Low streamflow in the Myakka River basin area in Florida: Florida Division of Geology Report of Investigations no. 53, 34 p.

Giovannelli, R.F., 1981, Relation between freshwater flow and salinity distributions in the Alafia River, Bullfrog Creek, and Hillsborough Bay, Florida: U.S. Geological Survey WaterResources Investigations 80-102, 62 p.

Hammett, K.M., 1985, Low-flow frequency distributions for streams in west-central Florida: U.S. Geological Survey Water-Resources Investigations Report 84-4299, 116 p.

---- 1990, Land use, water use, streamflow characteristics, and water-quality characteristics of the Charlotte Harbor inflow area, Florida: U.S. Geological Survey Water-Supply Paper 2359-A, $64 \mathrm{p}$.

Joyner, B.F., and Sutcliffe, Horace, Jr., 1976, Water resources of the Myakka River basin area, southwest Florida: U.S. Geological Survey Water-Resources Investigations 76-58, 85 p.

Marmer, H.A., 1951, Tidal datum planes: U.S. Department of Commerce, Coast and Geodetic Survey Special Publication no. $135,142 \mathrm{p}$.

Miller, R.L., Bradford, W.L., and Peters, N.E., 1988, Specific conductance--theoretical considerations and application to analytical quality control: U.S. Geological Survey WaterSupply Paper 2311, 16 p.

National Oceanic and Atmospheric Administration, 1987, Climatological data for Florida: v. 91, no. 13, p. 5 (published annually).

Rosenau, J.C., Faulkner, G.L., Hendry, C.W., and Hull, R.W., 1977, Springs of Florida (2d ed.): Florida Bureau of Geology Bulletin no. $31,461 \mathrm{p}$. 